\title{
Minireview
}

\section{Spatial and Temporal Oxygen Dynamics in Macrofaunal Burrows in Sediments: A Review of Analytical Tools and Observational Evidence}

\author{
HISASHI SATOH ${ }^{*}$, and SATOSHI OKABE ${ }^{1}$ \\ ${ }^{1}$ Division of Environmental Engineering, Faculty of Engineering, Hokkaido University, North-13, West-8, Sapporo \\ 060-8628, Japan
}

(Received November 23, 2012-Accepted February 12, 2013—Published online April 16, 2013)

The availability of benthic $\mathrm{O}_{2}$ plays a crucial role in benthic microbial communities and regulates many important biogeochemical processes. Burrowing activities of macrobenthos in the sediment significantly affect $\mathrm{O}_{2}$ distribution and its spatial and temporal dynamics in burrows, followed by alterations of sediment microbiology. Consequently, numerous research groups have investigated $\mathrm{O}_{2}$ dynamics in macrofaunal burrows. The introduction of powerful tools, such as microsensors and planar optodes, to sediment analysis has greatly enhanced our ability to measure $\mathrm{O}_{2}$ dynamics in burrows at high spatial and temporal resolution with minimal disturbance of the physical structure of the sediment. In this review, we summarize recent studies of $\mathrm{O}_{2}$-concentration measurements in burrows with $\mathrm{O}_{2}$ microsensors and $\mathrm{O}_{2}$ planar optodes. This manuscript mainly focuses on the fundamentals of $\mathrm{O}_{2}$ microsensors and $\mathrm{O}_{2}$ planar optodes, and their application in the direct measurement of the spatial and temporal dynamics of $\mathrm{O}_{2}$ concentrations in burrows, which have not previously been reviewed, and will be a useful supplement to recent literature reviews on $\mathrm{O}_{2}$ dynamics in macrofaunal burrows.

Key words: bioturbated sediment, macrofaunal burrow, $\mathrm{O}_{2}$ dynamics, $\mathrm{O}_{2}$ microsensor, $\mathrm{O}_{2}$ planar optode

\section{Introduction}

In aquatic ecosystems, it is obvious that the volume of the water column far exceeds the volume of the upper-surface layer of benthic sediment. However, ecological processes in an aquatic system, such as the biogeochemical carbon, nitrogen, phosphorus, and sulfur cycles, are predominantly regulated by microbial activities in the surface layer of the sediment, typically with depths of a few millimeters or centimeters, rather than by the integrated microbial activity of the entire water column $(2,3,4,24,70,77,78,83,84$, $104,144,145)$. This is because volume-specific microbial activity in the sediment surface, which hosts a high density of microorganisms, is typically 100 to 1,000 times higher than that in the water column (37). For example, it was estimated that up to $80 \%$ of the nitrogen needed by primary producers in shallow seas was provided by remineralization processes in the sediment (19).

Because an estuary is a transition zone between a river and an ocean, it is subject not only to marine influences (e.g., tides, waves, and influx of nutrients and saline water) but also riverine influences (e.g., fresh-water flow, influx of particles, and natural and anthropogenic input of nutrients, metals, and organic compounds) $(60,127,143)$. Inflow of both seawater and freshwater provides high levels of organic matter and nutrients in the sediment surface of an estuary. Moreover, the reduction in water flow in an estuary accelerates the accumulation of organic matter and nutrients on the sediment surface. In particular, this makes estuaries the most productive natural habitats among aquatic eco-

\footnotetext{
* Corresponding author. E-mail: qsatoh@eng.hokudai.ac.jp; Tel: +81-(0)11-706-6277; Fax: +81-(0)11-706-6277.
}

systems $(54,102,103)$. In addition, estuaries are often heavily polluted by biodegradable organic matter, nutrients, heavy metals, PCBs, hydrocarbons, pesticides and other microorganic contaminants $(47,61,66,69,93,98,140,144)$. As a result, estuarine sediments can act as a source or sink for environmentally relevant organic compounds, gases $\left(\mathrm{O}_{2}, \mathrm{CO}_{2}\right.$, $\mathrm{CH}_{4}$, and $\left.\mathrm{N}_{2} \mathrm{O}\right)$ and inorganic compounds $\left(\mathrm{NH}_{4}^{+}, \mathrm{NO}_{2}^{-}\right.$, $\mathrm{NO}_{3}{ }^{-}, \mathrm{PO}_{4}{ }^{3-}, \mathrm{SO}_{4}{ }^{2-}$, and $\left.\mathrm{H}_{2} \mathrm{~S}\right)$ in the aquatic ecosystem (21, $61,77,78)$. These gases and ions have a profound impact on water and air quality, and life in the biosphere $(2,5,8$, 9 ). Thus, it is highly important to quantify benthic turnover rates of organic and inorganic compounds, and to investigate the parameters regulating these processes.

It has long been recognized that by redistributing particles and modifying water fluxes via bioturbation and bioirrigation, macrofaunas living in the sediment (i.e., macrobenthos) have a significant effect on the physical, chemical and biological properties of the substratum and the interstitial water in these sediments. There have been many papers describing the impact of macrobenthos on elemental ( $\mathrm{C}$ and $\mathrm{N})$ cycles and on the enhanced transport and turnover reactions of organic and inorganic compounds and trace contaminants in sediments $(7,33,37,52,56,57,61,63,65,70,74,80,122$, 133). In contrast, surprisingly little attention, particularly in review papers, has been paid to the description of $\mathrm{O}_{2}$ concentrations and dynamics in macrofaunal burrows.

$\mathrm{O}_{2}$ is a key molecule for biogeochemical and metabolic processes occurring in the sediment $(30,37)$. It is produced by oxygenic photosynthetic organisms (cyanobacteria, algae and plants) in the presence of light, and is consumed as the preferred terminal electron acceptor in the biological breakdown of organic and inorganic compounds, as it is the most energetically favorable electron acceptor for facultative 
aerobic microorganisms (99). Therefore, a lack of available $\mathrm{O}_{2}$ can have a serious impact on aerobic microorganisms and macrobenthos. On the other hand, higher $\mathrm{O}_{2}$ levels are critical for anaerobic microorganisms and processes, as well as for aerobic organisms, as the formation of reactive oxygen species can interfere with cellular processes. The spatial distribution of $\mathrm{O}_{2}$ in the sediment can thus strongly affect biogeochemical processes and microbial community structures.

$\mathrm{O}_{2}$ rarely penetrates deeper parts of the sediment due to the presence of a diffusive boundary layer at the sediment-water interface, the high microbial- and chemicalconsumption rates of dense bacterial communities, and diffusion resistance in the sediment, as well as low solubility in water $(77,78,105)$. Typically, the $\mathrm{O}_{2}$ penetration depth is approximately a few millimeters and the boundary between the oxic and anoxic layers is usually found as a welldefined interface in the sediment surface (78). $\mathrm{O}_{2}$ concentration can vary strongly and dynamically depending on the activity of the macrobenthos and in response to environmental parameters such as temperature, light, liquid flow, and the availability of organic compounds and nutrients at the micrometer to millimeter scale $(6,30,37,57,64,83,88,90$, $105,123,124)$. Precise quantification of $\mathrm{O}_{2}$ distribution and dynamics is a prerequisite for understanding the regulation of biogeochemical cycles in sediments. Such spatial and temporal $\mathrm{O}_{2}$ dynamics in sediments has been successfully assessed with $\mathrm{O}_{2}$ microsensors and $\mathrm{O}_{2}$ planar optodes (126).

This review aims to summarize the current knowledge on spatial and temporal $\mathrm{O}_{2}$ dynamics in macrofaunal burrows in sediments. Effects of bioturbation on solute transport, organic-matter mineralization activities, and biogeochemical cycles have been studied extensively $(33,37,56,57,61,70$, $74,132,133,141)$, and it is beyond the scope of this review paper to cover the entire literature on this subject. Our goals are: (i) to present the principles behind and applications of $\mathrm{O}_{2}$ microsensors and $\mathrm{O}_{2}$ planar optodes as tools for $\mathrm{O}_{2}$ concentration measurements in macrofaunal burrows in bioturbated sediments at high spatial (sub-mm scale) and temporal (a few seconds) resolution; (ii) to provide experimental examples of direct measurements of spatial and temporal $\mathrm{O}_{2}$ dynamics in such burrows; and (iii) to summarize the current studies of $\mathrm{O}_{2}$ concentration measurements in burrows using $\mathrm{O}_{2}$ microsensors and $\mathrm{O}_{2}$ planar optodes.

\section{Effects of bioturbation on sediment characteristics}

Bioturbation is the activity of macrobenthos living in sediments to disperse sediment particles by relocation, tube construction, burrowing, and feeding. Macrobenthos living in tubes and burrows frequently or intermittently irrigate their burrows to introduce fresh oxygenated water for respiration and for suspended food particles, as well as to remove toxic metabolites; this irrigation generates liquid flow $(37,56,76$, $105,132)$. Increased liquid flow in the burrow enhances solute exchange between the sediment and the overlying water column. The advective transport of solutes is more rapid than by molecular diffusion because macrobenthos increase solute flux into or out of the sediment by as much as several orders of magnitude (92).
Bioirrigation has many consequences for the physical, chemical and biological properties of the sediment. Burrowing macrobenthos alter the sediment texture and structure (e.g., sediment porosity, permeability and particle size) by transporting particles (e.g., suspended soil, silt, organic particles, metal oxides and bacteria) into the sediment $(1,15,16,70)$. Labile particles are used for the growth and respiration of macrobenthos and microorganisms, whereas inert particles are deposited onto the burrow wall. Macrobenthos can vary the components and concentrations of organic compounds by breaking them down. These metabolites are then used by the microorganisms living on the burrow wall.

Dissolved compounds, such as $\mathrm{O}_{2}$, oxidized inorganic compounds (e.g., $\mathrm{NO}_{2}{ }^{-}, \mathrm{NO}_{3}{ }^{-}, \mathrm{SO}_{4}{ }^{2-}$ and oxidized metal ions), organic compounds and nutrients, are also transported through the burrows into the deep sediment by bioirrigation $(6,15,59,75,147)$. Their enhanced transport into the sediment allows extension of the oxic-anoxic interface into otherwise reduced sediment $(43,105)$. Metabolites from the macrobenthos, and reduced compounds (e.g., $\mathrm{NH}_{4}{ }^{+}$, $\mathrm{H}_{2} \mathrm{~S}$ and reduced iron and manganese) in the deep sediment, are removed from the burrow and into the water column in the opposite direction. Consequently, the activities of macrobenthos also affect water quality in the overlying water column.

Other effects of macrobenthos are the development of biofilms and mucus deposition on the burrow wall, which can create a highly reactive layer and alter the radial diffusion of solutes across the sediment-water interface (1). Thus, the physicochemical properties of the burrow wall are different from those on both the sediment surface and in the surrounding sediment.

The input of various types of organic compounds and excess nutrients to the burrow changes the redox conditions, generating a variety of niches for both aerobic and anaerobic microorganisms and supporting the proliferation of a large number of highly diversified microorganisms, thus enhancing their activities on the burrow wall in the deeper layers of the sediment $(10,37,61,62,105)$. In addition, irrigation during the burrow-maintenance activities of the macrobenthos allows the transport of aerobic microorganisms from the overlying oxygenated water into burrows in deeper layers of sediment. In this way, the activities of macrobenthos can affect the abundance and activities of microorganisms on the burrow wall by providing substrates and/or by grazing and predation. Thus, bioirrigation has significant effects not only on the components and concentrations of organic and inorganic compounds, but also on the microorganisms and the rate of associated biogeochemical processes in the sediment. For instance, recent studies have shown that bacterial abundance and activity on the burrow wall were 10 -fold those in the surrounding bulk sediments (61), and that the sedimentary phosphorus cycle was also strongly enhanced through bioturbation $(98,139)$.

More importantly, because macrobenthos activities vary temporally and spatially, bioirrigation increases heterogeneity in the sediment's biogeochemical conditions. Bottomdwelling macrobenthos (e.g., polychaetes and insect larvae) create unique physical structures (such as burrows and tubes) 
in the sediment by reworking and burrowing activities. Photographs of burrows in bioturbated sediments show burrow openings, U-shaped burrows and series of tunnels and chambers $(12,42,43,79)$. Through the activity of macrobenthos, one-dimensional diagenetic stratification of physicochemical and biological microenvironments in the sediment is transformed into three-dimensional, complex and time-dependent stratification. Their burrowing activities considerably increase the area of the sediment-water interface available for diffusive solute exchange, as well as the area of oxic-anoxic boundaries in the entire sediment. Satoh et al. (105) estimated the specific surface area of the burrow walls in the upper $350 \mathrm{~mm}$ of the sediment to be $26 \mathrm{~m}^{2} \mathrm{~m}^{-3}$. The tubes and burrows differ in size, appearance and composition, depending on the identity, mode of life and habits, density, and depth distribution of the macrobenthos that inhabit them. The presence of thalassinidean shrimp burrows has been shown to increase the sediment surface area by up to nine times (43). Teal et al. (130) calculated the global volume of bioturbated sediment to be $20,700 \mathrm{~km}^{3}$, based on a conservative estimate of 360 million $\mathrm{km}^{2}$ for the ocean area. It is clear that macrobenthos provide a variety of microorganisms with a substantial number of niches in the sediment.

Because measurement of $\mathrm{O}_{2}$ concentrations inside the burrows is methodologically difficult, several different techniques have been tried. In early studies, $\mathrm{O}_{2}$ concentrations, as well as other nutrient concentrations (e.g., inorganic nitrogenous compounds), in the burrows were measured using ex situ approaches. Koike and Mukai (53) measured concentrations of $\mathrm{O}_{2}$ and inorganic nitrogenous compounds in burrows occupied by the shrimps Callianassa japonica and Upogebia major by directly collecting liquid samples from inside the burrows. These studies provided only net results, integrating the spatial and temporal $\mathrm{O}_{2}$ dynamics of the macrofaunal activities, because the $\mathrm{O}_{2}$ concentration measured was the mean value throughout the burrow. Kristensen (58) monitored the $\mathrm{O}_{2}$ consumption of Nereis virens, $N$. succinea and $N$. diversicolor by monitoring incurrent and excurrent water. This method tends to underestimate the effects of macrobenthos activities because the macrobenthos under consideration were confined to an artificial tube, causing shifts in their behavior due to the stress associated with the unnatural environmental conditions. Thus, such approaches are not suitable for studies of $\mathrm{O}_{2}$ concentrations in real macrofaunal burrows (14). To overcome these obstacles, an electrochemical $\mathrm{O}_{2}$ microsensor has been employed to determine in situ $\mathrm{O}_{2}$ concentrations in and around a single macrofaunal burrow at high spatial and temporal resolution $(10,105,121)$.

\section{Oxygen microsensors}

Characteristics. An $\mathrm{O}_{2}$ microsensor is a needle-shaped electrochemical sensor with a tip diameter of approximately $10 \mu \mathrm{m}$. Its unique characteristics allow for $\mathrm{O}_{2}$ concentration measurements in the sediment at very high temporal and spatial resolution. The $90 \%$ response time for a typical $\mathrm{O}_{2}$ microsensor is less than $1 \mathrm{~s}(85,86,87,95,96,109) . \mathrm{O}_{2}$ concentration measurements in microbial communities are recommended at intervals of twice the tip diameter (112), and hence the spatial resolution of the $\mathrm{O}_{2}$ microsensor will be approximately $20 \mu \mathrm{m}$. Therefore, the $\mathrm{O}_{2}$ microsensor is, at present, one of the best tools for the direct in situ measurement of $\mathrm{O}_{2}$ concentrations at the sediment surface.

Three types of electrochemical microsensors are most frequently used in environmental applications: amperometric microsensors, potentiometric microsensors and microbiosensors, which are actually amperometric microsensors that incorporate a biological or enzymatic reaction into the sensor tip $(17,20,22,36,68,71,94,95,102,113)$. The $\mathrm{O}_{2}$ microsensor falls into the amperometric category, which measures the current caused by the electrochemical reaction (an oxidation-reduction reaction) of $\mathrm{O}_{2}$ at the tip of the microsensor. In recent work on the measurement of $\mathrm{O}_{2}$ in sediments and biofilms, a miniaturized Clark-type $\mathrm{O}_{2}$ sensor with a guard cathode has been preferred to the cathode-type $\mathrm{O}_{2}$ microsensor $(82,95,96,105,106,107,108,110,135)$.

Construction and measuring principle. In the Clark-type $\mathrm{O}_{2}$ microsensor (Fig. 1), the tip is coated with an electrically insulating membrane of silicone rubber, which is extremely permeable to $\mathrm{O}_{2}$ (96). The tip of a working cathode, which is a platinum wire electroplated with gold, is fixed just behind the membrane, otherwise its response time becomes too long. The microsensor is filled with an electrolyte solution of $1 \mathrm{M}$ $\mathrm{KCl}$, into which an internal guard cathode and a reference electrode, which are silver wires electrochemically coated with $\mathrm{AgCl}$ ( $\mathrm{Ag} / \mathrm{AgCl}$ wire), are immersed (95). If air bubbles remain in the microsensor, they must be removed so that vacuum conditions are in place. The working cathode, the reference electrode and the guard cathode are connected to a very sensitive ammeter (Fig. 2), termed a picoammeter, with a range down to $1 \mathrm{pA}$ (Unisense A/S, Aarhus, Denmark) (http://www.unisense.com/). The electrochemical reaction is driven by the potential difference between the working cathode and the reference electrode. For $\mathrm{O}_{2}$ measurement, the working cathode is polarized by the battery to about $-0.8 \mathrm{~V}$ against the internal reference electrode. It should

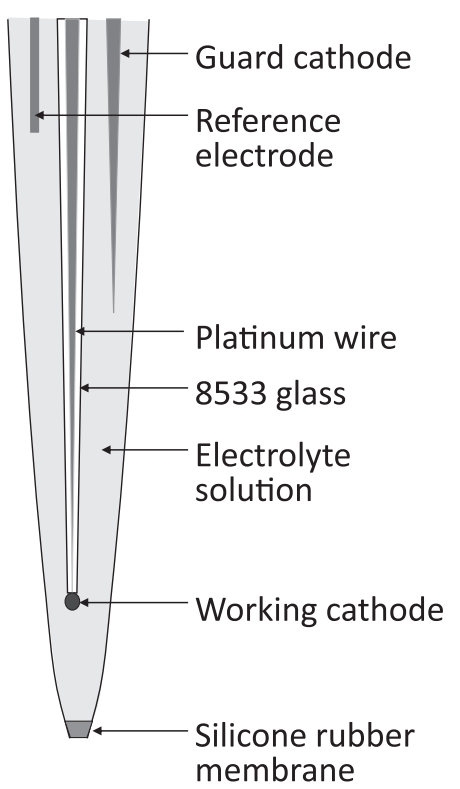

Fig. 1. Schematic drawing of a Clark-type $\mathrm{O}_{2}$ microsensor. 


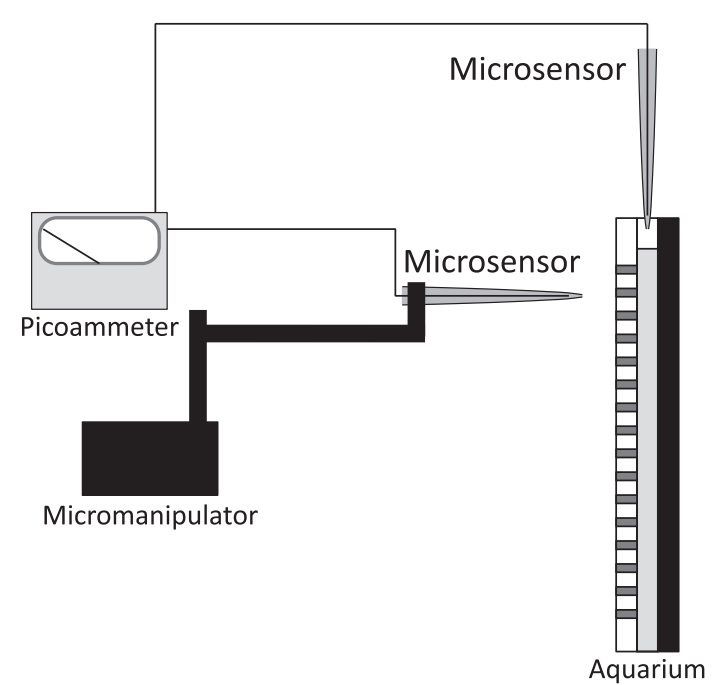

Fig. 2. Experimental apparatus for monitoring $\mathrm{O}_{2}$ concentrations in sediment and an infaunal burrow.

be noted that the polarization potential is specific to each type of amperometric microsensor (e.g., $\mathrm{O}_{2}, \mathrm{H}_{2} \mathrm{~S}, \mathrm{H}_{2}, \mathrm{~N}_{2} \mathrm{O}$ and NO) $(27,49,95,97,113)$. Driven by external $\mathrm{O}_{2}$ partial pressure, $\mathrm{O}_{2}$ from the sample solution penetrates the membrane and is then reduced at the working cathode tip and thus the presence of $\mathrm{O}_{2}$ is registered. The current originating from the reduction of $\mathrm{O}_{2}$ at the working cathode tip should be proportional to $\mathrm{O}_{2}$ partial pressure in the surrounding solution. The picoammeter converts the reduction current to a signal.

Because of the small size of the cathode tip, diffusion is rapid relative to the convective transport of $\mathrm{O}_{2}$ to the cathode tip. Because of the small size and short diffusion path, the $90 \%$ response time can be less than $0.5 \mathrm{~s}(95)$. The electrolyte solution serves as electrical shielding for the working cathode to minimize electrical noise, allowing the $\mathrm{O}_{2}$ microsensor to be mounted on benthic landers for in situ measurements (37). The internal guard cathode is also polarized and removes all $\mathrm{O}_{2}$ diffusing toward the working cathode from the internal electrolyte reservoir, thus minimizing zero-current and polarization time. The signal from a typical $\mathrm{O}_{2}$ microsensor is much more stable than that from a cathode-type $\mathrm{O}_{2}$ microsensor, and current drift is $1 \%$ per hour (13). As the $\mathrm{O}_{2}$ microsensor responds linearly to changes in $\mathrm{O}_{2}$ concentrations, two-point calibration is sufficient (e.g., zero $\mathrm{mg} \mathrm{L}^{-1}$ $\mathrm{O}_{2}$ and full air saturation).

\section{Oxygen planar optodes}

Although $\mathrm{O}_{2}$ concentration dynamics in burrows have been successfully monitored with $\mathrm{O}_{2}$ microsensors $(10,105$, $121,137)$, the monitoring of spatial and temporal $\mathrm{O}_{2}$ dynamics in the bioturbated sediment poses a further challenge. Problems arise in this case because of the patchiness of the macrobenthos and microorganisms, and their activities. Because the $\mathrm{O}_{2}$ microsensor measures $\mathrm{O}_{2}$ concentration at a single point, one-dimensional $\mathrm{O}_{2}$-concentration profiles at several distinct positions are obtained by stepwise insertion in the sediment. Therefore, from these one-dimensional results it is difficult to extrapolate two- or three-dimensional
$\mathrm{O}_{2}$ distributions in complex bioturbated sediment on larger scales (centimeter to meter scales). Simultaneous measurement of $\mathrm{O}_{2}$ concentrations at several points requires a series of $\mathrm{O}_{2}$ microsensors with associated recording devices, which is expensive and impractical in most cases. Thus, due to limited horizontal resolution, attributed to the onedimensional nature of $\mathrm{O}_{2}$ microsensors, monitoring twodimensional $\mathrm{O}_{2}$ distribution in bioturbated sediments using $\mathrm{O}_{2}$ microsensors is a very difficult and time-consuming, if not impossible, task. Furthermore, measuring several $\mathrm{O}_{2}$ profiles at several points in the sediment in order to simultaneously describe temporal $\mathrm{O}_{2}$ dynamics is laborious, especially under non-steady-state conditions. Recently, however, the development of planar optodes has enabled us to visualize two-dimensional $\mathrm{O}_{2}$ distribution in the sediments.

Indicators. The setup for planar-optode measurement has previously been described in detail $(40,46)$ and is thus only briefly presented here. The measuring principle behind the $\mathrm{O}_{2}$ planar optode is based on the dynamic quenching of a luminescent fluorophore by $\mathrm{O}_{2}\left(\mathrm{O}_{2}\right.$ indicator $)$, where $\mathrm{O}_{2}$ decreases the fluorescence quantum yield of the $\mathrm{O}_{2}$ indicator $(40,46,51)$. The most frequently employed $\mathrm{O}_{2}$-quenchable fluorophores are ruthenium(II)-tris-4,7-diphenyl-1,10phenathroline $(28,40,46,101,116,117,134)$, platinum(II)meso-tetra(pentafluorophenyl)porphyrin (32, 116), and platinum-octaethyl-porphyrine (46). Staal et al. (116) recently developed a new transparent optode for life-timebased microscopic imaging of $\mathrm{O}_{2}$, which is based on the use of iridium(III) acetylacetonato-bis(3-[benzothiazol-2-yl]-7[diethylamino]-coumarin) as the $\mathrm{O}_{2}$ indicator. Compared to $\mathrm{O}_{2}$ optodes based on the ruthenium(II) polypyridyl complex or the platinum(II) porphyrin, the new planar optode has the advantages of being brighter, having a more homogeneous and smaller pixel-to-pixel variation over the sensor area, and having lower temperature dependency. These characteristics allow for much shorter exposure times and thus lead to very short response times, less noisy $\mathrm{O}_{2}$ image analysis and simplification of the calibration procedure. A short response time is critical in $\mathrm{O}_{2}$ optodes, for example, when the $\mathrm{O}_{2}$ concentration in a sample changes quickly under non-steadystate conditions.

Construction and measuring principle. The $\mathrm{O}_{2}$ indicator is immobilized on a support foil, a microscope slide, a transparent polyethylene terephthalate carrier foil with plasticized PVC, or an organically modified sol-gel or polystyrene $(28,32,40,46,101,116,134)$. The typical thickness of the $\mathrm{O}_{2}$ indicator layer in the planar optodes is less than $20 \mu \mathrm{m}$. The planar optode is placed on the inside of an aquarium wall (Fig. 3). Excitation light with specific wavelengths for each $\mathrm{O}_{2}$ indicator is supplied from the outside. The image of the $\mathrm{O}_{2}$-dependent fluorescent signal emitted by the planar optode is recorded by a digital charge-coupled device (CCD) camera, and thus yields a description of two-dimensional $\mathrm{O}_{2}$ distribution. Therefore, the spatial resolution of the $\mathrm{O}_{2}$ planar optode is dependent on the optical performance of the setup, properties of the indicators, and blurring of the signal due to oxygen diffusion in the $\mathrm{O}_{2}$ indicator layer (32). Spatial resolution can easily be changed by modifying the optical configuration in front of the CCD camera; for example, images covering an area of $26 \times 25 \mathrm{~mm}$ and $70 \times 50 \mathrm{~mm}$ 


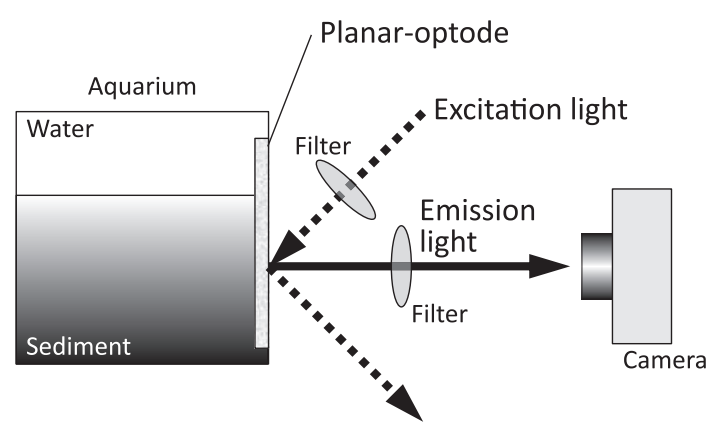

Fig. 3. Schematic drawing of the experimental setup for a planaroptode measurement.

correspond to spatial resolutions of $50 \mu \mathrm{m}$ per pixel (54) and $105 \mu \mathrm{m}$ per pixel, respectively (142).

In the presence of $\mathrm{O}_{2}$, the fluorescence intensity of the $\mathrm{O}_{2}$ indicator decreases predictably due to the quenching process (40). In contrast to the $\mathrm{O}_{2}$ microsensor described above, the calibration curve for the $\mathrm{O}_{2}$ planar optode, based on dynamic quenching of the luminescence of the $\mathrm{O}_{2}$ indicator, is nonlinear. Instead, the signal of the $\mathrm{O}_{2}$ planar optode can be described by the Stern-Volmer equation,

$\frac{\mathrm{I}}{I_{0}}=\frac{1}{1+K_{S V} C}$

where $I_{0}$ and $I$ are fluorescence intensities in the absence and presence of $\mathrm{O}_{2}$, respectively; $K_{S V}$ is the Stern-Volmer constant; and $C$ is the $\mathrm{O}_{2}$ concentration (81). This simple Stern-Volmer equation is, however, only strictly valid for ideal systems, such as diluted solutions of fluorophore in a liquid solvent. Thus, slightly modified versions of the SternVollmer equation are sometimes preferred because they more adequately describe the response of the optodes $(32,39,46$, 134).

In addition, the fluorescence lifetime (i.e., decay time) of the $\mathrm{O}_{2}$ indicator can be used for $\mathrm{O}_{2}$ measurements $(46,131)$. In this case, the measuring principle relies on dynamic quenching of the indicator luminescence in response to $\mathrm{O}_{2}$. The decay time is a direct function of the phase of the luminescent light, which can be used directly for $\mathrm{O}_{2}$ detection. Luminescence-lifetime imaging has advantages over intensity-based imaging and allows enhancement of the contrast and background suppression of unwanted luminescence contributions in the image (46). Moreover, lifetime imaging does not depend on intensity variations due to photobleaching and variable indicator concentrations, and calibration-free sensing applications are also possible. The basic working principles of lifetime-based optodes can be found in previous reports $(40,46,67,131)$. In addition to the modifications described above, many different $\mathrm{O}_{2}$ indicators and imaging setups have been developed to meet the requirements of various specific experimental purposes $(46,54,81,92,115)$.

\section{An example of fine-scale oxygen measurements in macrofaunal burrows with an $\mathrm{O}_{2}$ microsensor}

Introduction. In this section, an example of the application of $\mathrm{O}_{2}$ microsensors to measure $\mathrm{O}_{2}$ concentrations in burrows constructed by polychaete (Tylorrhynchus heterochaetus) is presented. Many studies have reported direct $\mathrm{O}_{2-}$ concentration measurements in burrows without sampling (see next section) and have shown evidence of enhanced mass transport through the burrows. However, measurements with $\mathrm{O}_{2}$ microsensors were limited to depths of just a few centimeters from the sediment surface due to poor accessibility of the $\mathrm{O}_{2}$ microsensor, and the exact position of the burrow was unknown. Because the macrobenthos commonly live in deeper parts of the sediment (e.g., >100 mm below the sediment surface) and play an important role in mass transport into the sediment, measurements of solute concentrations in deeper parts of the sediment are essential to investigate the effect of the macrobenthos on mass transport. Therefore, we studied $\mathrm{O}_{2}$ concentrations in burrows with $\mathrm{O}_{2}$ microsensors to provide direct evidence of mass transport into deeper parts of the sediment through burrows.

Materials and methods. Sediment from the Niida River estuary in Hachinohe City, Japan, was selected, in which a large number of burrows have been constructed by a macrobenthos, Tylorrhynchus heterochaetus, which inhabits the intertidal zone of Japanese estuaries. To directly measure $\mathrm{O}_{2}$ concentration profiles in the burrows and bulk sediment, we constructed a continuous-flow aquarium with agar slits in one side (105). River water and sediment samples were collected in the intertidal area of the Niida River, which is located approximately $1.5 \mathrm{~km}$ from the river mouth $(77,78$, 105). Grab samples of sediments were collected in November 2002. The sediment samples were passed through 1-mm mesh to remove pebbles, large detritus particles and indigenous macrobenthos.

The concentration profiles of $\mathrm{O}_{2}$ and oxidation-reduction potential (ORP) were measured in the laboratory using microsensors, as described by Satoh et al. (105). The microsensors for ORP, which were made from a platinum wire coated with a glass micropipette, were constructed and calibrated as described by Jang et al. (48). All ORP data reported in this paper were relative to the $\mathrm{Ag} / \mathrm{AgCl}$ reference sensor. To directly determine $\mathrm{O}_{2}$ concentrations around and inside the burrows, we constructed an aquarium from acrylic plates (105). Forty-five slits $(5 \times 50 \mathrm{~mm})$ filled with $3 \%$ agar plate were made in one side of the aquarium (Fig. 4), allowing us to determine the burrow structure and microsensor position in the burrow. The aquarium was filled with the sediment collected at the study site. When a macrobenthos ( $T$. heterochaetus) was placed on the sediment surface in the aquarium, it immediately began to dig a burrow in the sediment. River water was continuously fed through the

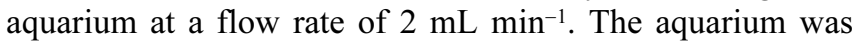
maintained at $20^{\circ} \mathrm{C}$ and in dark conditions. After $3 \mathrm{~d}$, the macrobenthos had created visible burrows down to $400 \mathrm{~mm}$.

To measure $\mathrm{O}_{2}$ concentrations in the burrow or bulk sediment in deeper parts of the sediment, the $\mathrm{O}_{2}$ microsensor was inserted into the burrow through the agar plate to the center of the aquarium (i.e., $10 \mathrm{~mm}$ from the agar surface). An $\mathrm{O}_{2}$ microsensor was mounted on a motor-driven micromanipulator (model ACV-104-HP; Chuo Precision Industrial Co., Ltd., Tokyo, Japan) (Fig. 2). $\mathrm{O}_{2}$ concentration profiles in the biofilms were obtained by using the micromanipulator at intervals of 50 to $500 \mathrm{~mm}$ from the agar surface (or bulk liquid) into the sediment. The position of the microsensor tip 
A

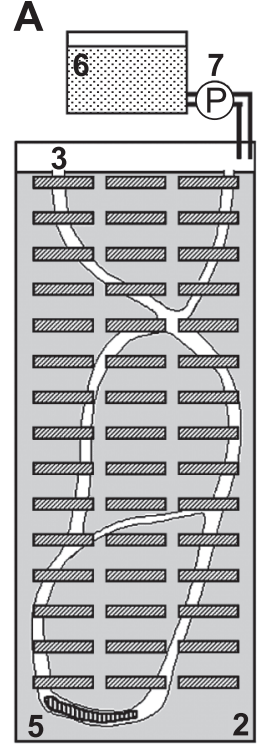

B

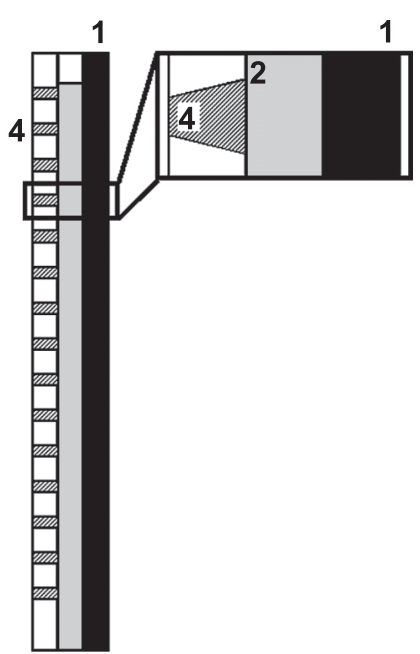

Fig. 4. Schematic drawing of an aquarium: 1, sideboard; 2, sediment; 3 , infaunal burrow; 4 , agar plate; 5 , an infauna; 6 , tank filled with river water; 7, pump. (A) Front view. (B) Side view. (C) Close-up view of the side view enclosed by the box in panel B.

was determined with a dissecting microscope (model Stemi 2000; Carl Zeiss). In order to determine $\mathrm{O}_{2}$ concentrations inside the burrow, on the burrow wall (i.e., the burrowsediment interface) and in the bulk sediment, the $\mathrm{O}_{2}$ microsensor was inserted into four different points in the sediment, positioned laterally at a depth of $80 \mathrm{~mm}$ from the sediment surface (see Fig. 2). In addition, the $\mathrm{O}_{2}$ microsensor was inserted from the top of the aquarium to measure a twodimensional contour plot of $\mathrm{O}_{2}$ concentrations at the sediment surface (Fig. 2). Eleven vertical $\mathrm{O}_{2}$-concentration profiles were measured at $0.5 \mathrm{~mm}$ to $3 \mathrm{~mm}$ intervals along a transection of the sediment surface. A contour plot was constructed from the profiles. Microprofiles for $\mathrm{O}_{2}$ and ORP were determined only once at different positions in the sediment.

The profiles of ORP levels were also measured at a cross section of the sediment in a flow cell filled with a synthetic medium (105). To ensure that steady-state profiles were obtained, the sediment was incubated in the medium at $20^{\circ} \mathrm{C}$ for more than $30 \mathrm{~min}$ before taking the measurements. The details of the measurements are described elsewhere (105).

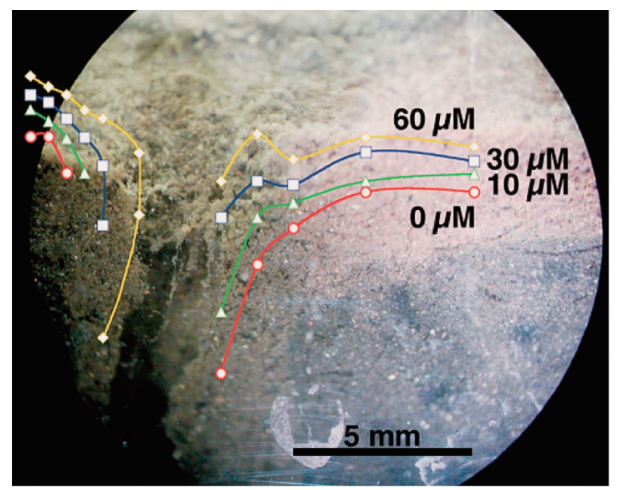

Results. Many burrow openings (approximately 2000 ind. $\mathrm{m}^{-2}$ ), with diameters of approximately $5 \mathrm{~mm}$, were found on the sediment surface at the study site during low tide. The visible burrows extended down to a depth of at least 400 $\mathrm{mm}$. The burrow walls were covered with thin oxidized lightbrown layers (Fig. 5) (105). The color of the burrow wall was similar to that of the sediment surface. Further information on the sediment characteristics at the study site and the physical and chemical parameters in the river water can be found elsewhere $(77,78,105)$.

A representative two-dimensional contour plot of $\mathrm{O}_{2}$ concentrations at the sediment surface, constructed from 11 vertical $\mathrm{O}_{2}$ concentration profiles, is shown in Fig. 5. In this case, the $\mathrm{O}_{2}$ concentration in the overlying water was ca. 80 $\mu \mathrm{M}$. The contour plot of $\mathrm{O}_{2}$ around the burrow opening is parallel to the burrow structure, demonstrating that $\mathrm{O}_{2}$ was transported into the sediment through the burrow. Fluffy brown biofilm developed on the surface and burrow wall. Biofilm thickness was ca. $5 \mathrm{~mm}$. During the microsensor measurements, we occasionally found that suspended particles flowed in the burrow and the fluffy biofilm on the burrow wall oscillated, which proved that water did actually flow through the burrow.

The $\mathrm{O}_{2}$ microsensor was inserted horizontally through the agar plate of the aquarium into 4 different points in the sediment at a depth of $80 \mathrm{~mm}$ from the sediment surface (Fig. 6A). Fig. 6B shows $\mathrm{O}_{2}$-concentration profiles in the burrow and in the surrounding bulk sediment. In this case, the $\mathrm{O}_{2}$ concentration in the overlying water was ca. $190 \mu \mathrm{M}$. The $\mathrm{O}_{2}$ concentration of ca. $210 \mu \mathrm{M}$ at the agar surface decreased to $60-90 \mu \mathrm{M}$ in the agar plate. When the $\mathrm{O}_{2}$ microsensor was inserted at the center of the burrow (point 1 indicated in Fig. 6A), the $\mathrm{O}_{2}$ concentration increased toward the center of the burrow (at a point $10 \mathrm{~mm}$ from the agar surface in Fig. 6B). In contrast, the $\mathrm{O}_{2}$ concentration remained almost unchanged at the burrow-sediment interface (point 2). $\mathrm{O}_{2}$ concentrations in the surrounding bulk sediment decreased further, down to less than $10 \mu \mathrm{M}$ at a point $10 \mathrm{~mm}$ from the agar surface (points 3 and 4). These results clearly show the horizontal $\mathrm{O}_{2}$-concentration profile from the center of the burrow to the surrounding anoxic bulk sediment.

Temporal changes in the $\mathrm{O}_{2}$ concentration in the burrow were monitored by inserting and fixing an $\mathrm{O}_{2}$ microsensor at the center of the burrow (i.e., $10 \mathrm{~mm}$ from agar surface) at a depth of $170 \mathrm{~mm}$ from the sediment surface, and

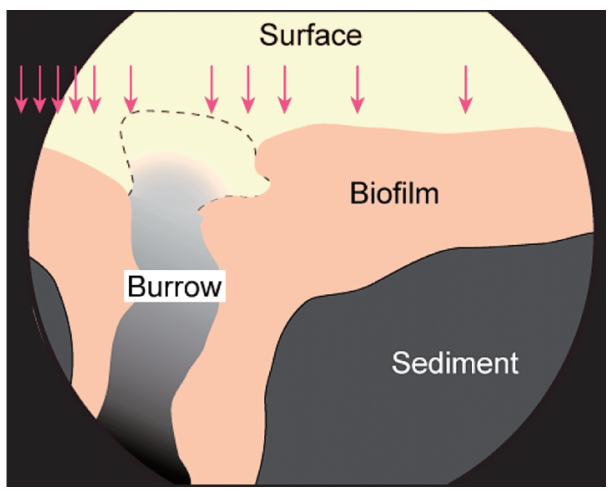

Fig. 5. A representative two-dimensional contour plot of $\mathrm{O}_{2}$ concentration in the sediment (left) and drawing of a cross section of the sediment indicated in the left panel. A microsensor was inserted at 11 points (arrows in the right panel). 
A

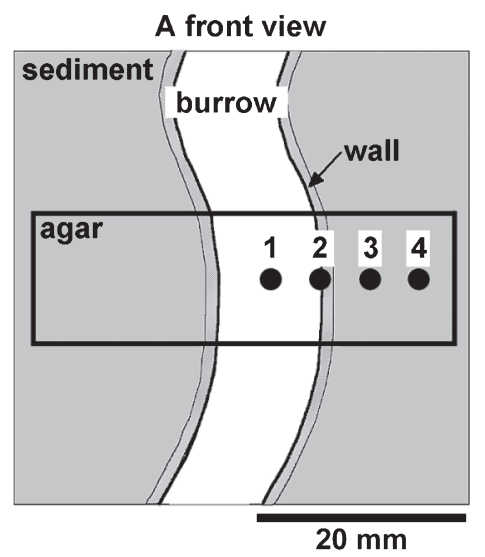

B

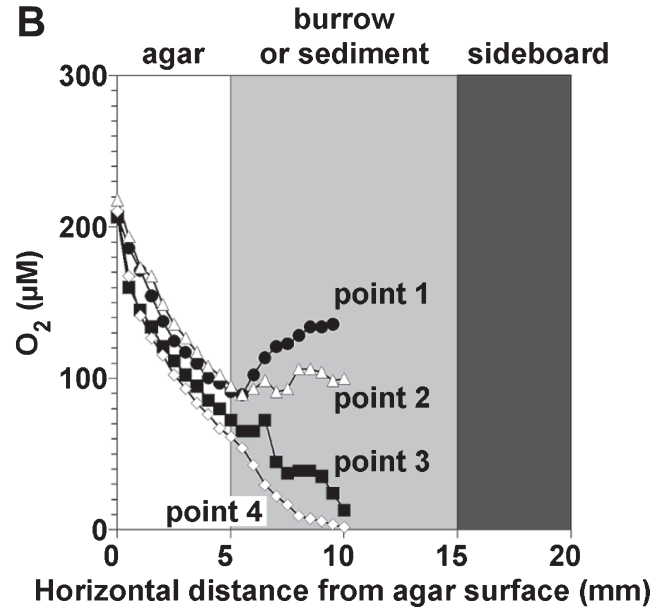

Fig. 6. Horizontal $\mathrm{O}_{2}$ concentration profiles in the burrow and in the surrounding bulk sediment at a depth of $80 \mathrm{~mm}$ from the sediment surface.

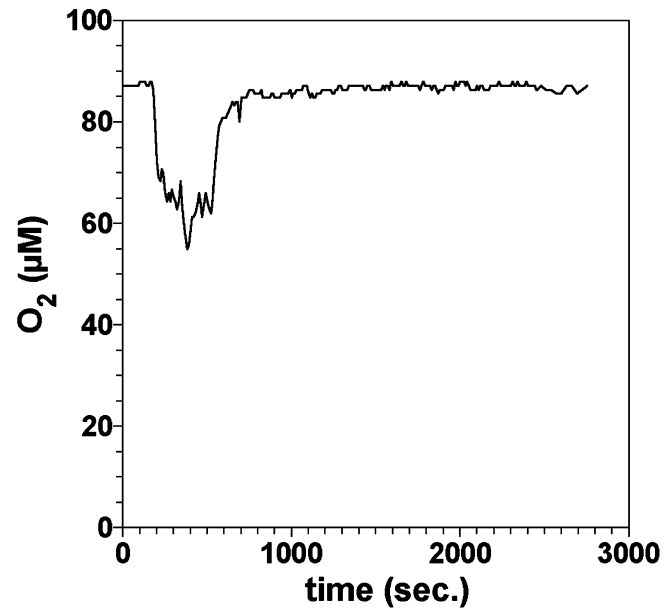

Fig. 7. Temporal changes in $\mathrm{O}_{2}$ concentration in the burrow.

continuously recording $\mathrm{O}_{2}$ concentrations (Fig. 7). In this case, the $\mathrm{O}_{2}$ concentration in the overlying water was ca. 190 $\mu \mathrm{M}$. The $\mathrm{O}_{2}$ concentration was ca. $90 \mu \mathrm{M}$ when the $\mathrm{O}_{2}$ microsensor was inserted $(0 \mathrm{~s})$. The $\mathrm{O}_{2}$ concentration started to decrease at $170 \mathrm{~s}$, reached the minimum value (ca. $55 \mu \mathrm{M}$ ) at $380 \mathrm{~s}$, and then finally returned almost to the initial level (ca. $85 \mu \mathrm{M}$ ) at $750 \mathrm{~s}$. Interestingly, we found that the macrobenthos wriggled during the period when the $\mathrm{O}_{2}$ concentration decreased. Movement of the macrobenthos and changes in the $\mathrm{O}_{2}$ concentration in the burrow were not observed for at least $2,000 \mathrm{~s}$ after the initial $750 \mathrm{~s}$. The burrows of the macrobenthos extended into anoxic sediment; thus, they must pump overlying oxic water through their burrows to meet their respiratory needs. Burrow irrigation can also be required for feeding, metabolite removal, and avoidance of the toxic effects of sulfide in anoxic pore waters (34). Bioirrigation introduces $\mathrm{O}_{2}$ and nutrients into an otherwise anoxic sediment, which enhances solute exchange between the water column and pore waters, thereby influencing the biogeochemical cycling of nutrients.

Many studies have aimed to measure solute concentrations in burrows with microsensors $(11,38,72,73,138)$; however, all of the data were limited to the upper parts of the sediments (a few $\mathrm{cm}$ deep). In this study, we constructed and used an aquarium with agar slits in a side panel to overcome this limitation. To determine the $\mathrm{O}_{2}$ concentration profile along the burrow structure, the $\mathrm{O}_{2}$ microsensor was inserted through the agar slits of the aquarium into the center of the burrow to different sediment depths (105). In this case, the $\mathrm{O}_{2}$ concentration in the overlying water was ca. $190 \mu \mathrm{M}$. The $\mathrm{O}_{2}$ concentration in the burrow decreased from this value to $120 \mu \mathrm{M}$ at a depth of $80 \mathrm{~mm}$ due to respiration of the macrobenthos and microorganisms, but below this depth, the decrease in $\mathrm{O}_{2}$ concentration was moderate. Interestingly, $\mathrm{O}_{2}$ still existed in the burrow even at a depth of $350 \mathrm{~mm}$ (105). This was attributed to the irrigation activity of the macrobenthos to exchange water with low concentrations of $\mathrm{O}_{2}$ and metabolites with the overlying fresh water (Fig. 7) (58). In contrast, the $\mathrm{O}_{2}$ penetration depth was only a few millimeters into the sediment surface around the burrow opening (Fig. 5). Using the newly developed aquarium, we could directly determine, for the first time, the $\mathrm{O}_{2}$ concentration profile in the burrow down to a depth of $350 \mathrm{~mm}$ from the sediment surface. This result provided direct evidence of the contribution of the macrobenthos to $\mathrm{O}_{2}$ transport, through the burrow, to deeper sediment.

Our aquarium had the advantages of being able to observe the exact positions of the burrows in the sediment and to directly measure the $\mathrm{O}_{2}$ concentration profiles in and around the burrows in deeper parts of the sediment. The main disadvantage was, however, that $\mathrm{O}_{2}$ diffused into the burrow and sediment through the agar plate, as indicated by the $\mathrm{O}_{2}$ concentration gradients in the agar plate (Fig. 6B). The $\mathrm{O}_{2}$ transport rates through the agar plate corresponded to ca. $5 \%$ of the total $\mathrm{O}_{2}$ consumption rates in the burrow wall (105). Thus, $\mathrm{O}_{2}$ concentrations in the burrow were slightly overestimated in this study; however, this does not negate the observed trends in the results presented here.

Moreover, steady-state ORP profiles on burrow walls were measured in a cross-section of the sediment, which was collected without disturbing the physical structure of the cross-section of the sediment at the same sampling site (105). ORP microsensors were inserted into 3 points of the cross 
A

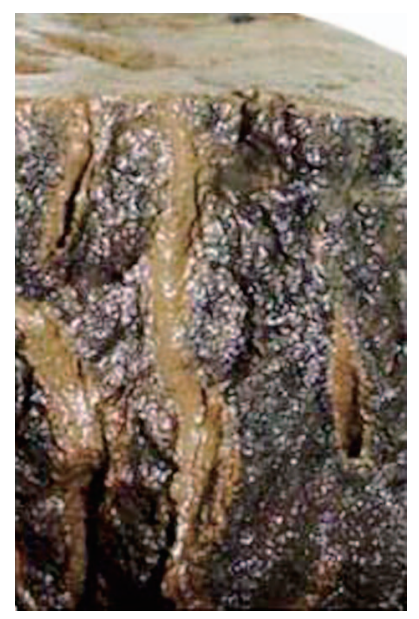

B
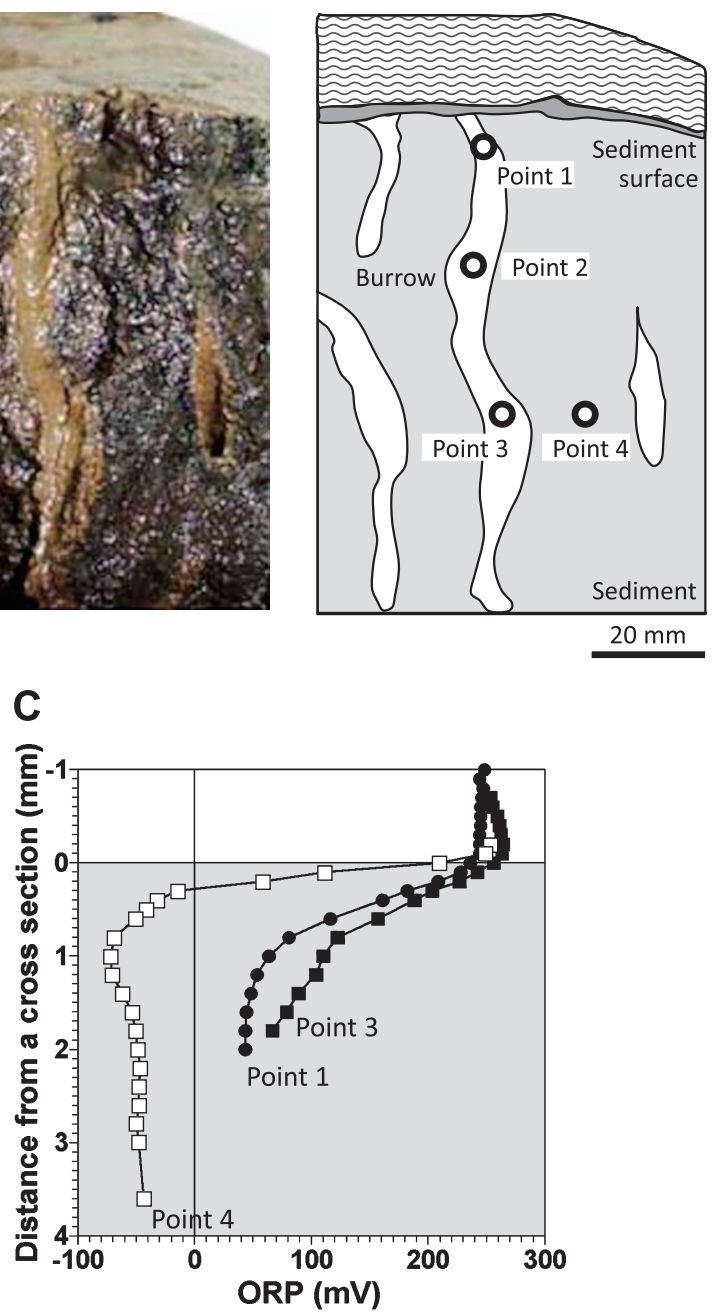

Fig. 8. ORP profiles at 3 points (Point 1 [O], Point $3[\boldsymbol{\square}]$, and Point $4[\square]$ ) in a cross section of the sediment. (A) Photograph of the cross-section of the sediment. (B) Drawing of the cross-section of the sediment indicated in panel A. Points 1 to 4 indicate the points where the microelectrodes were inserted. (C) ORP profiles at 3 points. Zero on the horizontal axis corresponds to the surface of the cross-section.

section; the burrow wall at depths of $5 \mathrm{~mm}$ (point 1) and 50 $\mathrm{mm}$ (point 3) and the bulk sediment at a depth of $50 \mathrm{~mm}$ (point 4) from the sediment surface (Fig. 8B). The ORP level declined sharply in the upper $0.5 \mathrm{~mm}$ of the bulk sediment (point 4) in comparison to at the burrow wall (points 1 and 3) (Fig. 8C). ORP levels at a depth of ca. $2 \mathrm{~mm}$ from the cross section were ca. $+50 \mathrm{mV}$ at the burrow wall (points 1 and 3), whereas ca. $-30 \mathrm{mV}$ in the bulk sediment (point 4), indicating that the burrow-wall sediment was more oxygenated than the bulk sediment. These results clearly indicate that the layered structure of oxygenated and reduced zones, found at the sediment surface, was created at the burrow wall.

The higher levels of $\mathrm{O}_{2}$ and ORP in the burrow walls altered the abundance, diversity and activity of ammoniaoxidizing bacteria (AOB) and nitrite-oxidizing bacteria (NOB) in the burrow walls rather than in the bulk sediment (105). Real-time quantitative PCR (Q-PCR) assay demonstrated that $\mathrm{AOB}$ and Nitrospira-like NOB-specific 16S rRNA gene copy numbers in the burrow walls were comparable with those in the sediment surfaces and higher than those in the bulk sediment at the same depth. The 16S rRNA gene-cloning analysis revealed that betaproteobacterial AOB communities in the sediment surface and burrow walls were dominated by Nitrosomonas sp. strain Nm143-like sequences. The second most frequently detected clones recovered from the sediment surface were affiliated with the Nitrosomonas marina lineage, whereas they were affiliated with the Nitrosospira briensis lineage in the burrow walls. Microelectrode measurements showed higher $\mathrm{NH}_{4}{ }^{+}$consumption activity at the burrow wall than in the surrounding sediment. These results clearly demonstrated that the infaunal burrows stimulated $\mathrm{O}_{2}$ and mass transport into the sediment in which otherwise reducing conditions prevailed, resulting in the development of high $\mathrm{NH}_{4}{ }^{+}$consumption capacity. Consequently, the infaunal burrow became an important site for $\mathrm{NH}_{4}{ }^{+}$consumption in the intertidal sediment.

\section{Spatial and temporal dynamics of oxygen concentrations in macrofaunal burrows: a review of the recent literature}

In previous studies, spatial and temporal $\mathrm{O}_{2}$ dynamics in macrofaunal burrows in sediments were measured with $\mathrm{O}_{2}$ microsensors and $\mathrm{O}_{2}$ planar optodes at high spatial and temporal resolution. Table 1 summarizes these papers, listing the macrobenthos species that created the burrows and the range of $\mathrm{O}_{2}$ concentrations in the burrows. To date, studies to investigate $\mathrm{O}_{2}$ concentrations in the burrows have focused mainly on the burrows created by polychaetes and insect larvae, which inhabit sediments in estuarine, lake or river waters.

$\mathrm{O}_{2}$ was introduced into burrows in deeper sediment layers by the activities of the macrobenthos (e.g., bioirrigation). Microsensor measurements demonstrated that $\mathrm{O}_{2}$ was present in the burrows, at least at the points where the $\mathrm{O}_{2}$ microsensor was inserted (at depths of 3.5 to $50 \mathrm{~mm}$ ). $\mathrm{O}_{2}$ concentrations in the burrows differed depending on the burrow inhabitant. Furthermore, $\mathrm{O}_{2}$ planar optodes allowed $\mathrm{O}_{2}$-concentration measurements in deeper parts of the sediments (to depths of $500 \mathrm{~mm}$ ) than when using $\mathrm{O}_{2}$ microsensors. It should be noted that our aquarium also allowed for $\mathrm{O}_{2}$ measurements in burrows in deeper parts of the sediment (to depths of 350 $\mathrm{mm})$ (105).

$\mathrm{O}_{2}$ concentrations in the burrows fluctuated over time and ranged from $0 \%$ to $100 \%$ of air saturation in response to bioirrigation activity of the macrobenthos (Table 1). The burrows were intermittently irrigated in a sequence of pumping events by the macrobenthos, followed by a period of rest, which could be interpreted from the temporal variation in the $\mathrm{O}_{2}$ concentration (91). In our study, the time interval between the initial $\mathrm{O}_{2}$ decrease, due to the discharge of water with lower $\mathrm{O}_{2}$ concentration and with metabolites from the macrobenthos and microorganisms, and the moment the concentration returns to its peak after replacement with fresh oxygenated water, is considered to be the duration of the pumping event (170 s to $750 \mathrm{~s}$ in Fig. 7). The duration of the maximum $\mathrm{O}_{2}$ concentration is considered to be the rest period. Due to discontinuous irrigation, $\mathrm{O}_{2}$ concentrations in the burrows were highly variable over a timescale of minutes. The dynamic range of the $\mathrm{O}_{2}$ concentrations in the burrows 
Table 1. Summary of $\mathrm{O}_{2}$ concentrations and their temporal fluctuations in burrows created by different macrobenthos species reported in previous studies. $\mathrm{O}_{2}$ concentrations were determined with an $\mathrm{O}_{2}$ microsensor or $\mathrm{O}_{2}$ planar optode. The macrobenthos species and the location of the study site are presented. Each source is listed by number in the literature cited

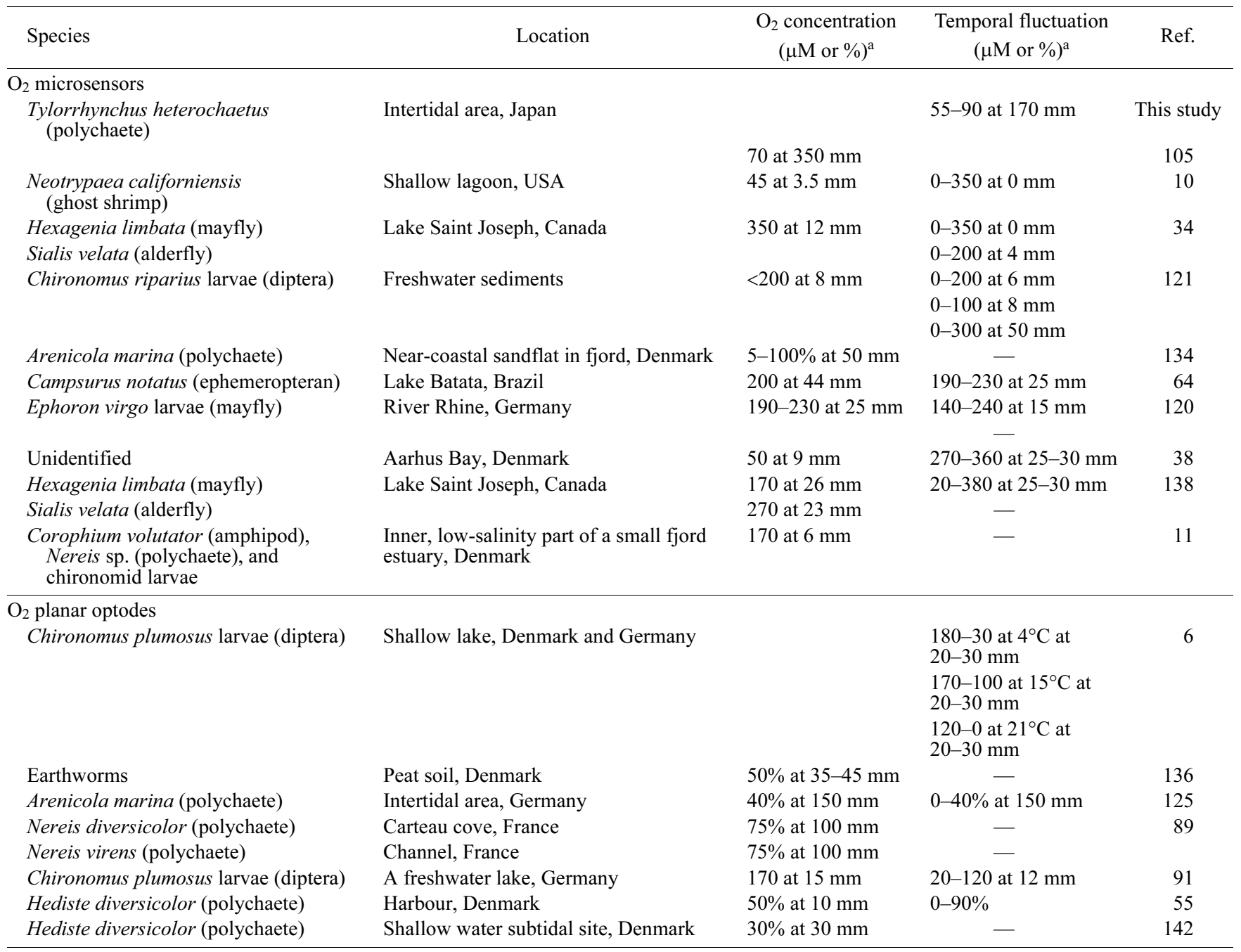

a The concentrations are indicated as $\mu \mathrm{M}$ or percentage of air saturation.

and the cycle of pumping and resting events, differed depending on the macrobenthos species (138) and temperature (6), probably because the activities of the macrobenthos vary among species and with the environmental conditions in the burrows.

Macrobenthos are quantitatively important with respect to enhancing the area of the oxic-anoxic interface in sediments with their burrowing activity. Satoh et al. (105) studied the burrows created by Tylorrhynchus heterochaetus with ca. 5 $\mathrm{mm}$ diameter and roughly estimated that the area of the oxicanoxic interface in the upper $350 \mathrm{~mm}$ of bioturbated sediment was approximately 9 times higher than the area of the sediment surface. Likewise, the presence of thalassinidean shrimp burrows increased the area of the oxic-anoxic interface by up to 9 times (43). A similar expansion of the area of the oxic-anoxic interface has also been demonstrated previously (Table 2). It is obvious that the increase in the area of the oxic-anoxic interface is dependent on the identity, density, mode of life and habits (feeding strategy, tolerance for low $\mathrm{O}_{2}$ concentration and tolerance towards toxic $\mathrm{H}_{2} \mathrm{~S}$ and $\mathrm{NH}_{4}^{+}$), and depth distribution of the macrobenthos. Teal et al. (130) calculated the global volume of bioturbated sediment to be $20,700 \mathrm{~km}^{3}$, based on a conservative estimate of the ocean area of 360 million $\mathrm{km}^{2}$, indicating a significant impact of the macrobenthos activities on chemical environments in sediments on a global scale.

Microsensors can detect $\mathrm{O}_{2}$ concentrations in the burrows directly and with minimum disturbance and a rapid response. As other types of microsensors (for $\mathrm{H}_{2} \mathrm{~S}, \mathrm{H}_{2}, \mathrm{~N}_{2} \mathrm{O}, \mathrm{NO}$, $\mathrm{pH}$, redox level, and flow-velocity measurement) are commercially available (Unisense $\mathrm{A} / \mathrm{S}$ ) and liquid ion-exchange (LIX)-based microsensors $\left(\mathrm{NH}_{4}{ }^{+}, \mathrm{NO}_{2}{ }^{-}, \mathrm{NO}_{3}{ }^{-}\right.$and $\left.\mathrm{pH}\right)$ are easy to construct (23), microsensor measurements enable us to analyze nitrogen and sulfur cycles, as well as the $\mathrm{O}_{2}$ dynamics in macrofaunal burrows. The detailed quantitative analysis of $\mathrm{O}_{2}$ concentrations in the burrows with an $\mathrm{O}_{2}$ microsensor was limited to depths of $50 \mathrm{~mm}$ from the sediment surface, due to low accessibility of the microsensor and uncertainty of the exact position of the burrows. On the other hand, the $\mathrm{O}_{2}$ planar optode allowed $\mathrm{O}_{2}$-concentration 
Table 2. Summary of the ratios of the oxic sediment area and volume associated with burrows relative to the area and volume of oxic surface sediment, respectively, reported in previous studies. The macrobenthos species and the location of the study site are presented. Each source is listed by number in the literature cited

\begin{tabular}{|c|c|c|c|c|}
\hline Species & Location & $\begin{array}{l}\text { Ratio of } \\
\text { area }(-)\end{array}$ & $\begin{array}{c}\text { Ratio of } \\
\text { volume }(-)\end{array}$ & Ref. \\
\hline Tylorrhynchus heterochaetus (polychaete) & Intertidal area, Japan & 9.1 & & 105 \\
\hline Hediste diversicolor (polychaete) & Shallow water subtidal site, Denmark & & $0.54-0.7$ & 142 \\
\hline Hexagenia limbata (mayfly) & Lake Saint Joseph, Canada & & $<0.26$ & 138 \\
\hline Nereid polychaetes & & $1.3-5$ & & 57 \\
\hline $\begin{array}{l}\text { Nereis diversicolor (polychaete), polychaetes } \\
\text { (especially Pygospia elegans) and oligochaetes }\end{array}$ & Sandy sediment in harbour and bay, Denmark & $2.5-5$ & & 29 \\
\hline Thalassinidean shrimp & & 9 & & 43 \\
\hline
\end{tabular}

measurements in deeper parts of the sediment than possible with the $\mathrm{O}_{2}$ microsensor (Table 1). In addition, the $\mathrm{O}_{2}$ planar optode allows for two-dimensional time-lapse measurements; however, the $\mathrm{O}_{2}$ planar optode is not always in direct contact with the burrows, resulting in the underestimation of $\mathrm{O}_{2}$ concentrations in the burrow. Likewise, the optode could not detect $\mathrm{O}_{2}$ in either the feeding pocket or in the advective zone (134). In addition, $\mathrm{O}_{2}$ measurements in sediments with the $\mathrm{O}_{2}$ planar optode potentially result in physical changes to the sediment structure due to insertion of the optode into the sediment (6). Photobleaching of the indicator can hinder reliable and long-term measurements. The $\mathrm{O}_{2}$ microsensor also infrequently suffers from drift. Consequently, the choice of appropriate tools is an important prerequisite to accurately measure $\mathrm{O}_{2}$ concentrations in the bioturbated sediment. The combined use of an $\mathrm{O}_{2}$ planar optode and $\mathrm{O}_{2}$ microsensor allowed for more accurate and reliable measurements of $\mathrm{O}_{2}$ concentrations in sediments $(41,90)$.

\section{Conclusions and future directions}

During the last couples of decades, much effort has been devoted to investigating $\mathrm{O}_{2}$ concentrations in bioturbated sediments. Currently, $\mathrm{O}_{2}$ concentrations can be measured at high spatial and temporal resolution with $\mathrm{O}_{2}$ microsensors and $\mathrm{O}_{2}$ planar optodes. Extensive studies have provided considerable insight into $\mathrm{O}_{2}$ distributions and their spatial and temporal dynamics in macrofaunal burrows in sediments, as described above. Microsensor measurements clearly demonstrate that the macrofaunal burrow facilitates $\mathrm{O}_{2}$ transport into deeper sediment, in which otherwise reducing conditions prevail. $\mathrm{O}_{2}$ was detected in macrofaunal burrows at depths of $500 \mathrm{~mm}$ in the sediment, whereas the $\mathrm{O}_{2}$ penetration depth at the sediment surface was only a few millimeters. Thereby, the area of the oxic-anoxic interface in the sediments was enhanced by up to 9 times that of the area of the sediment surface as a result of the burrowing activity of the macrobenthos. Moreover, $\mathrm{O}_{2}$ distribution patterns were spatially and temporally dynamic in response to a sequence of pumping events by the macrobenthos followed by a period of rest.

However, $\mathrm{O}_{2}$ microsensors and $\mathrm{O}_{2}$ planar optodes have only been used to a very limited extent in studies concerning the distribution, transport and dynamics of $\mathrm{O}_{2}$ in macrofaunal burrows and sediments; therefore, up until now, little has been known about the biogeochemical cycles of carbon, nitrogen and sulfur in the bioturbated sediment. Future investigations should aim to map the concentrations of $\mathrm{CO}_{2}$, $\mathrm{CH}_{4}, \mathrm{NH}_{4}{ }^{+}, \mathrm{NO}_{2}{ }^{-}, \mathrm{NO}_{3}{ }^{-}, \mathrm{NO}, \mathrm{N}_{2} \mathrm{O}, \mathrm{H}_{2} \mathrm{~S}$, metals and the $\mathrm{pH}$ in the burrows. Planar optodes selective for $\mathrm{CO}_{2}(115,147)$, $\mathrm{NH}_{4}^{+}(128)$ and $\mathrm{pH}(114,118,146)$ are available; however, the types of indicators for planar optodes are limited. Hafuka et al. (44) reported a fluorescent molecule capable of recognizing heavy-metal ions, which suggests the possibility of developing corresponding planar optodes. In contrast, microsensors for $\mathrm{H}_{2} \mathrm{~S}, \mathrm{H}_{2}, \mathrm{~N}_{2} \mathrm{O}, \mathrm{NO}, \mathrm{pH}$, and redox potential are commercially available (Unisense $\mathrm{A} / \mathrm{S}$ ), and LIX-based microsensors $\left(\mathrm{NH}_{4}{ }^{+}, \mathrm{NO}_{2}{ }^{-}, \mathrm{NO}_{3}{ }^{-}\right.$and $\left.\mathrm{pH}\right)$ are easy to construct $(23,36)$. In situ two-dimensional distribution of $\mathrm{H}_{2} \mathrm{~S}$ has also been determined by diffusive gradients in the thin films (DGT)-computer-imaging densitometry (CID) technique (26). The combination of $\mathrm{O}_{2}$ microsensors and planar optodes with those for other dissolved gases and ions can enhance our understanding of the biogeochemical processes occurring in bioturbated sediments.

The biogeochemical processes in bioturbated sediments are not only affected by dissolved gases and ions, but also by many other factors, such as particle size and porosity in the sediment, transport properties (diffusion and advection), and the abundance, distribution and diversity of microorganisms. Although a microsensor for flow-velocity measurements is commercially available (Unisense A/S) (100), and permeability can be estimated by nuclear magnetic resonance (NMR) (18), determination of physical properties in the sediment on the submillimeter scale is still difficult. Development of technology to determine the physical properties of burrows and sediments is urgently needed. On the other hand, the abundance and diversity of microbial communities has been frequently studied using molecular techniques, such as 16S rRNA gene clone libraries, FISH, DGGE and T-RFLP $(25,31,35,45,50,111,129)$. Knowledge of these physical and/or microbial properties in burrows could be related directly or indirectly to the results obtained with $\mathrm{O}_{2}$ microsensors and $\mathrm{O}_{2}$ planar optodes.

Most of the studies discussed in this review were conducted in experimental mesocosms in laboratories. Only a few studies have performed in situ measurements of $\mathrm{O}_{2}$ concentrations in sediment, accomplished using autonomous benthic-lander systems that carry benthic chambers and profiling units $(37,41,142)$. Although the in situ temperature and bottom-water $\mathrm{O}_{2}$ concentrations of the recovered sediment cores were maintained as closely as possible in the laboratory, the measurements introduced artifacts that affected $\mathrm{O}_{2}$ distribution, as well as microbial activities due 
to the disturbance of the sediment structure during core sampling and improper establishment of in situ conditions during the measurements. Hence, trustworthy results can only be obtained by in situ analysis.

\section{Acknowledgements}

This research was financially supported by a Grant-in-Aid for Scientific Research (grant number 13650593) from the Japan Society for the Promotion of Science (JSPS).

\section{References}

1. Aller, R.C. 1983. The importance of the diffusive permeability of animal burrow linings in determining marine sediment chemistry. J. Mar. Res. 41:299-322.

2. Amachi, S. 2008. Microbial contribution to global iodine cycling: volatilization, accumulation, reduction, oxidation, and sorption of iodine. Microbes Environ. 23:269-276.

3. Amano, T., I. Yoshinaga, K. Okada, T. Yamagishi, S. Ueda, A. Obuchi, Y. Sako, and Y. Suwa. 2007. Detection of anammox activity and diversity of anammox bacteria-related 16S rRNA genes in coastal marine sediment in Japan. Microbes Environ. 22:232-242.

4. Amano, T., I. Yoshinaga, T. Yamagishi, V.T. Chu, T.T. Pham, S. Ueda, K. Kato, Y. Sako, and Y. Suwa. 2011. Contribution of anammox bacteria to benthic nitrogen cycling in a mangrove forest and shrimp ponds, Haiphong, Vietnam. Microbes Environ. 26:1-6.

5. Archer, D., and E. Meier-Reimer. 1994. Effect of deep-sea sedimentary calcite preservation on atmospheric $\mathrm{CO}_{2}$ concentration. Nature 6460:260-263.

6. Askaer, L., B. Elberling, R.N. Glud, M. Kuhl, F.R. Lauritsen, and H.R. Joensen. 2010. Soil heterogeneity effects on $\mathrm{O}_{2}$ distribution and $\mathrm{CH}_{4}$ emissions from wetlands: In situ and mesocosm studies with planar $\mathrm{O}_{2}$ optodes and membrane inlet mass spectrometry. Soil Biol. Biochem. 42:2254-2265.

7. Behrens, J.W., H.J. Stahl, J.F. Steffensen, and R.N. Glud. 2007. Oxygen dynamics around buried lesser sandeels Ammodytes tobianus (Linnaeus 1785): mode of ventilation and oxygen requirements. J. Exp. Biol. 210:1006-1014.

8. Berner, R.A. 1987. Models for carbon and sulfur cycles and atmospheric oxygen - application to paleozoic geologic history. Am. J. Sci. 287:177-196.

9. Berner, R.A., and D.E. Canfield. 1989. A new model for atmospheric oxygen over phanerozoic time. Am. J. Sci. 289:333-361.

10. Bertics, V.J., and W. Ziebis. 2009. Biodiversity of benthic microbial communities in bioturbated coastal sediments is controlled by geochemical microniches. ISME J. 3:1269-1285.

11. Binnerup, S.J., K. Jensen, N.P. Revsbech, M.H. Jensen, and J. Sorensen. 1992. Denitrification, dissimilatory reduction of nitrate to ammonium, and nitrification in a bioturbated estuarine sediment as measured with ${ }^{15} \mathrm{~N}$ and microsensor techniques. Appl. Environ. Microbiol. 58:303-313.

12. Bird, F.L., and G.C.B. Poore. 1999. Functional burrow morphology of Biffarius arenosus (Decapoda: Callianassidae) from southern Australia. Mar. Biol. 134:77-87.

13. Breuer, E.R., G.T.W. Law, C. Woulds, G.L. Cowie, G.B Shimmield, O. Peppe, M. Schwartz, and S. McKinlay. 2009. Sedimentary oxygen consumption and microdistribution at sites across the Arabian Sea oxygen minimum zone (Pakistan margin) Deep-Sea Res. Pt. II 56:296-304.

14. Chapman, P.M., F.Y. Wang, J.D. Germano, and G. Batley. 2002. Pore water testing and analysis: the good, the bad, and the ugly. Mar. Pollut. Bull. 44:359-366.

15. Ciutat, A., P. Anschutz, M. Gerino, and A. Boudou. 2005. Effects of bioturbation on cadmium transfer and distribution into freshwater sediments. Environ. Toxicol. Chem. 24:1048-1058.

16. Ciutat, A., and A. Boudou. 2003. Bioturbation effects on cadmium and zinc transfers from a contaminated sediment and on metal bioavailability to benthic bivalves. Environ. Toxicol. Chem. 22:1574-1581

17. Cronenberg, C., B. Vangroen, D. de Beer, and H. Vandenheuvel. 1991. Oxygen-independent glucose microsensor based on glucoseoxidase. Anal. Chim. Acta 242:275-278.
18. Daigle, H., and B. Dugan. 2011. An improved technique for computing permeability from NMR measurements in mudstones. J. Geophys. Res.-Solid Earth 116:B08101.

19. Dale, A.W., and R. Prego. 2002. Physico-biogeochemical controls on benthic-pelagic coupling of nutrient fluxes and recycling in a coastal upwelling system. Mar. Ecol.-Prog. Ser. 235:15-28.

20. Damgaard, L.R., and N.P. Revsbech. 1997. A microscale biosensor for methane containing methanotrophic bacteria and an internal oxygen reservoir. Anal. Chem. 69:2262-2267.

21. Damgaard, L.R., N.P. Revsbech, and W. Reichardt. 1998. Use of an oxygen-insensitive microscale biosensor for methane to measure methane concentration profiles in a rice paddy. Appl. Environ. Microbiol. 64:864-870.

22. de Beer, D. 2000. Potentiometric microsensors for in situ measurements in aquatic environments, p. 161-194. In J. Buffle, and G. Horvai (ed.), In Situ Monitoring of Aquatic Systems: Chemical Analysis and Speciation. Wiley, New York.

23. de Beer, D., A. Schramm, C.M. Santegoeds, and M. Kuhl. 1997. A nitrite microsensor for profiling environmental biofilms. Appl. Environ. Microbiol. 63:973-977.

24. Denis, L., and N. Desroy. 2008. Consequences of spring phytodetritus sedimentation on the benthic compartment along a depth gradient in the Eastern English Channel. Mar. Pollut. Bull. 56:1844-1854.

25. Desnues, C., V.D. Michotey, A. Wieland, C. Zhizang, A. Fourcans, R. Duran, and P.C. Bonin. 2007. Seasonal and diel distributions of denitrifying and bacterial communities in a hypersaline microbial mat (Camargue, France). Water Res. 41:3407-3419.

26. Devries, C.R., and F.Y. Wang. 2003. In situ two-dimensional high-resolution profiling of sulfide in sediment interstitial waters. Environ. Sci. Technol. 37:792-797.

27. Ebert, A., and A. Brune. 1997. Hydrogen concentration profiles at the oxic-anoxic interface: a microsensor study of the hindgut of the wood-feeding lower termite Reticulitermes flavipes (Kollar). Appl. Environ. Microbiol. 63:4039-4046.

28. Elberling, B., L. Askaer, C.J. Jorgensen, H.P. Joensen, M. Kuhl, R.N. Glud, and F.R. Lauritsen. 2011. Linking soil $\mathrm{O}_{2}, \mathrm{CO}_{2}$, and $\mathrm{CH}_{4}$ concentrations in a wetland soil: Implications for $\mathrm{CO}_{2}$ and $\mathrm{CH}_{4}$ fluxes. Environ. Sci. Technol. 45:3393-3399.

29. Fenchel, T. 1996. Worm burrows and oxic microniches in marine sediments. 1. Spatial and temporal scales. Mar. Biol. 127:289-295.

30. Fenchel, T., and B. Finlay. 2008. Oxygen and the spatial structure of microbial communities. Biol. Rev. 83:553-569.

31. Fiore, M.D., B.A. Neilan, J.N. Copp, J.L.M. Rodrigues, S.M. Tsai, H. Lee, and J.T. Trevors. 2005. Characterization of nitrogen-fixing cyanobacteria in the Brazilian Amazon floodplain. Water Res. 39:5017-5026.

32. Fischer, J.P., and F. Wenzhofer. 2010. A novel planar optode setup for concurrent oxygen and light field imaging: Application to a benthic phototrophic community. Limnol. Oceanogr. Meth. 8:254268.

33. Gabet, E.J., O.J. Reichman, and E.W. Seabloom. 2003. The effects of bioturbation on soil processes and sediment transport. Annu. Rev. Earth Pl. Sc. 31:249-273.

34. Gallon, C., L. Hare, and A. Tessier. 2008. Surviving in anoxic surroundings: how burrowing aquatic insects create an oxic microhabitat. J. N. Am. Benthol. Soc. 27:570-580.

35. Gen-Fu, W., and Z. Xue-Ping. 2005. Characterization of phosphorus-releasing bacteria in a small eutrophic shallow lake, Eastern China. Water Res. 39:4623-4632.

36. Gieseke, A., and D. de Beer. 2004. Use of microelectrodes to measure in situ microbial activities in biofilms, sediments, and microbial mats, p. 1581-1612. In G.A. Kowalchuk, F.J. de Bruijn, I.M. Head, A.D.L. Akkermans, and D. van Elsas (ed.), Molecular Microbial Ecology Manual. Second edition. Vol. 2. Kluwer Academic Publishers, Dordrecht, The Netherlands.

37. Glud, R.N. 2008. Oxygen dynamics of marine sediments. Mar. Biol. Res. 4:243-289.

38. Glud, R.N., J.K. Gundersen, H. Roy, and B.B. Jorgensen. 2003. Seasonal dynamics of benthic $\mathrm{O}_{2}$ uptake in a semienclosed bay: Importance of diffusion and faunal activity. Limnol. Oceanogr. 48:1265-1276.

39. Glud, R.N., M. Kuhl, O. Kohls, and N.B. Ramsing. 1999 Heterogeneity of oxygen production and consumption in a photosynthetic microbial mat as studied by planar optodes. J. Phycol. 35:270-279. 
40. Glud, R.N., N.B. Ramsing, J.K. Gundersen, and I. Klimant. 1996 Planar optrodes: A new tool for fine scale measurements of twodimensional $\mathrm{O}_{2}$ distribution in benthic communities. Mar. Ecol.Prog. Ser. 140:217-226.

41. Glud, R.N., F. Wenzhofer, A. Tengberg, M. Middelboe, K. Oguri, and H. Kitazato. 2005. Distribution of oxygen in surface sediments from central Sagami Bay, Japan: In situ measurements by microelectrodes and planar optodes. Deep-Sea Res. Pt. I 52:1974-1987.

42. Gosselin, A., and L. Hare. 2003. Burrowing behavior of Chaoborus flavicans larvae and its ecological significance. J. N. Am. Benthol Soc. 22:575-581.

43. Griffis, R.B., and T.H. Suchanek. 1991. A model of burrow architecture and trophic modes in thalassinidean shrimp (Decapoda: Thalassinidea). Mar. Ecol.-Prog. Ser. 79:171-183.

44. Hafuka, A., H. Taniyama, S.H. Son, K. Yamada, M. Takahashi, S. Okabe, and H. Satoh. 2012. BODIPY-based ratiometric fluoroionophores with bidirectional spectral shifts for the selective recognition of heavy metal ions. B. Chem. Soc. Jpn. 86:37-44.

45. Haller, L., M. Tonolla, J. Zopfi, R. Peduzzi, W. Wildi, and J. Pote. 2011. Composition of bacterial and archaeal communities in freshwater sediments with different contamination levels (Lake Geneva, Switzerland). Water Res. 45:1213-1228.

46. Holst, G., O. Kohls, I. Klimant, B. Konig, M. Kuhl, and T. Richter. 1998. A modular luminescence lifetime imaging system for mapping oxygen distribution in biological samples. Sens. Actuator B-Chem. 51:163-170.

47. Hoss, S., T. Henschel, M. Haitzer, W. Traunspurger, and C.E.W Steinberg. 2001. Toxicity of cadmium to Caenorhabditis elegans (Nematoda) in whole sediment and pore water-The ambiguous role of organic matter. Environ. Toxicol. Chem. 20:2794-2801.

48. Jang, A., J.H. Lee, P.R. Bhadri, S.A. Kumar, W. Timmons, F.R Beyette, I. Papautsky, and P.L. Bishop. 2005. Miniaturized redox potential probe for in situ environmental monitoring. Environ. Sci. Technol. 39:6191-6197.

49. Jeroschewski, P., C. Steuckart, and M. Kuhl. 1996. An amperometric microsensor for the determination of $\mathrm{H}_{2} \mathrm{~S}$ in aquatic environments. Anal. Chem. 68:4351-4357.

50. Kjellin, J., S. Hallin, and A. Worman. 2007. Spatial variations in denitrification activity in wetland sediments explained by hydrology and denitrifying community structure. Water Res. 41:4710-4720.

51. Klimant, I., M. Kuhl, R.N. Glud, and G. Holst. 1997. Optical measurement of oxygen and temperature in microscale: strategies and biological applications. Sens. Actuator B-Chem. 38:29-37.

52. Kogure, K., and M. Wada. 2005. Impacts of macrobenthic bioturbation in marine sediment on bacterial metabolic activity. Microbes Environ. 20:191-199.

53. Koike, I., and H. Mukai. 1983. Oxygen and inorganic nitrogen contents and fluxes in burrows of the shrimps Callianassa japonica and Upogebia major. Mar. Ecol.-Prog. Ser. 12:185-190.

54. Kondo, R., K.J. Purdy, S.D.Q. Silva, and D.B. Nedwell. 2007. Spatial dynamics of sulphate-reducing bacterial compositions in sediment along a salinity gradient in a UK estuary. Microbes Environ. 22:11-19.

55. Konig, B., O. Kohls, G. Holst, R.N. Glud, and M. Kuhl. 2005 Fabrication and test of sol-gel based planar oxygen optodes for use in aquatic sediments. Mar. Chem. 97:262-276.

56. Kristensen, E. 2001. Impact of polychaetes (Nereis spp. and Arenicola marina) on carbon biogeochemistry in coastal marine sediments. Geochem. T. 12:92-103.

57. Kristensen, E. 2000. Organic matter diagenesis at the oxic/anoxic interface in coastal marine sediments, with emphasis on the role of burrowing animals. Hydrobiologia 426:1-24.

58. Kristensen, E. 1983. Ventilation and oxygen uptake by three species of Nereis (Annelida: Polychaeta). I. Effects of hypoxia. Mar. Ecol.Prog. Ser. 12:289-297.

59. Kristensen, E., T. Hansen, M. Delefosse, G.T. Banta, and C.O. Quintana. 2011. Contrasting effects of the polychaetes Marenzelleria viridis and Nereis diversicolor on benthic metabolism and solute transport in sandy coastal sediment. Mar. Ecol.-Prog. Ser. 425:125-139.

60. Langston, W., and J. Ridgway. 2006. Geological and geochemical influences on estuarine ecosystems, Chapter 4, p. 21-47. In I.S Zekster, B. Marker, J. Ridgway, L. Rogachevskaya, and G. Vartanyan (ed.), Geology and Ecosystems. Springer, New York.
61. Laverock, B., J.A. Gilbert, K. Tait, A.M. Osborn, and S. Widdicombe. 2011. Bioturbation: impact on the marine nitrogen cycle. Biochem. Soc. T. 39:315-320.

62. Laverock, B., C.J. Smith, K. Tait, A.M. Osborn, S. Widdicombe, and J.A. Gilbert. 2010. Bioturbating shrimp alter the structure and diversity of bacterial communities in coastal marine sediments. ISME J. 4:1531-1544.

63. Leal, J.J.F., F.D. Esteves, V.F. Farjalla, and A. Enrich-Prast. 2003 Effect of Campsurus notatus on $\mathrm{NH}_{4}^{+}$, DOC fluxes, $\mathrm{O}_{2}$ uptake and bacterioplankton production in experimental microcosms with sediment-water interface of an Amazonian lake impacted by bauxite tailings. Int. Rev. Hydrobiol. 88:167-178.

64. Leal, J.J.F., A. Enrich-Prast, F.D. Esteves, R. Bozelli, and V.F. Farjalla. 2005. Influence of Campsurus notatus bioturbation on oxygen profile and uptake in sediments of an Amazonian lake impacted by bauxite tailings. Arch. Hydrobiol. 162:557-574.

65. Leal, J.J.F., A.L.D. Furtado, F.D. Esteves, R.L. Bozelli, and M.P. Figueiredo-Barros. 2007. The role of Campsurus notatus (Ephemeroptera: Polymitarcytidae) bioturbation and sediment quality on potential gas fluxes in a tropical lake. Hydrobiologia 586:143-154.

66. Liebig, M., P. Egeler, J. Oehlmann, and T. Knacker. 2005 Bioaccumulation of ${ }^{14} \mathrm{C}-17-\alpha$-ethinylestradiol by the aquatic oligochaete Lumbriculus variegatus in spiked artificial sediment. Chemosphere 59:271-280.

67. Liebsch, G., I. Klimant, B. Frank, G. Holst, and O.S. Wolfbeis 2000. Luminescence lifetime imaging of oxygen, $\mathrm{pH}$, and carbon dioxide distribution using optical sensors. Appl. Spectrosc. 54:548 559.

68. Lorenzen, J., L.H. Larsen, T. Kjaer, and N.P. Revsbech. 1998. Biosensor determination of the microscale distribution of nitrate, nitrate assimilation, nitrification, and denitrification in a diatominhabited freshwater sediment. Appl. Environ. Microbiol. 64:32643269.

69. Mayer, P., M.M. Fernqvist, P.S. Christensen, U. Karlson, and S. Trapp. 2007. Enhanced diffusion of polycyclic aromatic hydrocarhons in artificial and natural aqueous solutions. Environ. Sci. Technol. 41:6148-6155.

70. Mermillod-Blondin, F., and R. Rosenberg. 2006. Ecosystem engineering: the impact of bioturbation on biogeochemical processes in marine and freshwater benthic habitats. Aquat. Sci. 68:434-442.

71. Meyer, R.L., L.H. Larsen, and N.P. Revsbech. 2002. Microscale biosensor for measurement of volatile fatty acids in anoxic environments. Appl. Environ. Microbiol. 68:1204-1210.

72. Meyers, M.B., H. Fossing, E.N. Powell. 1987. Microdistribution of interstitial meiofauna, oxygen and sulfide gradients, and the tubes of macro-infauna. Mar. Ecol.-Prog. Ser. 35:223-241.

73. Meyers, M.B., E.N. Powell, and H. Fossing. 1988. Movement of oxybiotic and thiobiotic meiofauna in response to changes in porewater oxygen and sulfide gradients around macro-infaunal tubes. Mar. Biol. 98:395-414.

74. Meysman, F.J.R., J.J. Middelburg, and C.H.R. Heip. 2006 Bioturbation: a fresh look at Darwin's last idea. Trends Ecol. Evol. 21:688-695.

75. Michaud, E., R.C. Aller, and G. Stora. 2010. Sedimentary organic matter distributions, burrowing activity, and biogeochemical cycling: Natural patterns and experimental artifacts. Estuar. Coast Shelf S. 90:21-34.

76. Middelburg, J.J., and L.A. Levin. 2009. Coastal hypoxia and sediment biogeochemistry. Biogeosciences 6:1273-1293.

77. Nakamura, Y., H. Satoh, T. Kindaichi, and S. Okabe. 2006 Community structure, abundance, and in situ activity of nitrifying bacteria in river sediments as determined by the combined use of molecular techniques and microelectrodes. Environ. Sci. Technol. 40:1532-1539.

78. Nakamura, Y., H. Satoh, S. Okabe, and Y. Watanabe. 2004 Photosynthesis in sediments determined at high spatial resolution by the use of microelectrodes. Water Res. 38:2440-2448.

79. Needham, H.R., C.A. Pilditch. A.M. Lohrer, and S.F. Thrush. 2010 Habitat dependence in the functional traits of Austrohelice crassa, a key bioturbating species. Mar. Ecol.-Prog. Ser. 414:179-193.

80. Nielsen, O.I., B. Gribsholt, and E. Kristensen. 2004. Microscale distribution of oxygen and nitrate in sediment inhabited by Nereis diversicolor: spatial patterns and estimated reaction rates. Aquat Microb. Ecol. 34:23-32. 
81. Oguri, K., H. Kitazato, and R.N. Glud. 2006. Platinum octaetylporphyrin based planar optodes combined with an UV-LED excitation light source: An ideal tool for high-resolution $\mathrm{O}_{2}$ imaging in $\mathrm{O}_{2}$ depleted environments. Mar. Chem. 100:95-107.

82. Okabe, S., T. Itoh, H. Satoh, and Y. Watanabe. 1999. Analyses of spatial distributions of sulfate-reducing bacteria and their activity in aerobic wastewater biofilms. Appl. Environ. Microbiol. 65:51075116.

83. Okabe, S., T. Kindaichi, and T. Ito. 2004. MAR-FISH-An ecophysiological approach to link phylogenetic affiliation and in situ metabolic activity of microorganisms at a single-cell resolution. Microbes Environ. 19:83-98.

84. Okabe, S., Y. Nakamura, and H. Satoh. 2012. Community structure and in situ activity of nitrifying bacteria in Phragmites rootassociated biofilms. Microbes Environ. 27:242-249.

85. Okabe, S., H. Satoh, and T. Kindaichi. 2011. A polyphasic approach to study ecophysiology of complex multispecies nitrifying biofilms, p. 163-184. In M.G. Klotz, and L.Y. Stein (ed.), Methods in Enzymology. Vol. 496. Academic Press, New York.

86. Okabe, S., H. Satoh, and Y. Watanabe. 1999. In situ analysis of nitrifying biofilms as determined by in situ hybridization and the use of microelectrodes. Appl. Environ. Microbiol. 65:3182-3191.

87. Okabe, S., H. Satoh, and Y. Watanabe. 2001. Analysis of microbia structure and function of nitrifying biofilms, p. 213-224. In R.J. Doyle (ed.), Methods in Enzymology. Vol. 337. Academic Press, New York

88. Otubu, J.E., J.V. Hunter, K.L. Francisco, and C.G. Uchrin. 2006. Temperature effects on tubificid worms and their relation to sediment oxygen demand. J. Environ. Sci. Heal. A 41:1607-1613.

89. Pischedda, L., J.C. Poggiale, P. Cuny, and F. Gilbert. 2008. Imaging oxygen distribution in marine sediments. The importance of bioturbation and sediment heterogeneity. Acta Biotheor. 56:123135 .

90. Polerecky, L., U. Franke, U. Werner, B. Grunwald, and D. de Beer. 2005. High spatial resolution measurement of oxygen consumption rates in permeable sediments. Limnol. Oceanogr. Meth. 3:75-85.

91. Polerecky, L., N. Volkenborn, and P. Stief. 2006. High temporal resolution oxygen imaging in bioirrigated sediments. Environ. Sci. Technol. 40:5763-5769.

92. Precht, E., U. Franke, L. Polerecky, and M. Huettel. 2004. Oxygen dynamics in permeable sediments with wave-driven pore water exchange. Limnol. Oceanogr. 49:693-705

93. Reible, D.D., V. Popov, K.T. Valsaraj, L.J. Thibodeaux, F. Lin, M. Dikshit, M.A. Todaro, and J.W. Fleeger. 1996. Contaminant fluxes from sediment due to tubificid oligochaete bioturbation. Water Res. 30:704-714

94. Revsbech, N.P. 2005. Analysis of microbial communities with electrochemical microsensors and microscale biosensors, p. 147166. In J.R. Leadbetter (ed.), Methods in Enzymology. Vol. 397. Academic Press, New York.

95. Revsbech, N.P. 1989. An oxygen microsensor with a guard cathode Limnol. Oceanogr. 34:474-478.

96. Revsbech, N.P., and B.B. Jørgensen. 1986. Microelectrodes: their use in microbial ecology, p. 293-352. In M. Marshall (ed.), Advances in Microbial Ecology. Vol. 9. Plenum, New York.

97. Revsbech, N.P., L.P. Nielsen, P.B. Christensen, and J. Sorensen. 1988. Combined oxygen and nitrous-oxide microsensor for denitrification studies. Appl. Environ. Microbiol. 54:2245-2249.

98. Reynolds, C.S., and P.S. Davies. 2001. Sources and bioavailability of phosphorus fractions in freshwaters: a British perspective. Biol. Rev. 76:27-64.

99. Rittmann, B.E., and P.L. McCarty. 2001. Environmental Biotechnology: Principles and Applications. McGraw-Hill, New York.

100. Roskosch, A., M. Hupfer, G. Nutzmann, and J. Lewandowski. 2011 Measurement techniques for quantification of pumping activity of invertebrates in small burrows. Fund. Appl. Limnol. 178:89-110.

101. Rysgaard, S., R.N. Glud, M.K. Sejr, M.E. Blicher, and H.J. Stahl. 2008. Denitrification activity and oxygen dynamics in Arctic sea ice. Polar Biol. 31:527-537.

102. Sakami, T. 2008. Seasonal and spatial variation of bacterial community structure in river-mouth areas of Gokasho Bay, Japan Microbes Environ. 23:277-284.
103. Sakami, T. 2012. Distribution of ammonia-oxidizing archaea and bacteria in the surface sediments of Matsushima Bay in relation to environmental variables. Microbes Environ. 27:61-66.

104. Satoh, H., Y. Miura, I. Tsushima, and S. Okabe. 2007. Layered structure of bacterial and archaeal communities and their in situ activities in anaerobic granules. Appl. Environ. Microbiol. 73:73007307.

105. Satoh, H., Y. Nakamura, and S. Okabe. 2007. Influences of infaunal burrows on the community structure and activity of ammoniaoxidizing bacteria in intertidal sediments. Appl. Environ. Microbiol. 73:1341-1348.

106. Satoh, H., Y. Nakamura, H. Ono, and S. Okabe. 2003. Effect of oxygen concentration on nitrification and denitrification in single activated sludge flocs. Biotechnol. Bioeng. 83:604-607.

107. Satoh, H., M. Odagiri, T. Ito, and S. Okabe. 2009. Microbial community structures and in situ sulfate-reducing and sulfur-oxidizing activities in biofilms developed on mortar specimens in a corroded sewer system. Water Res. 43:4729-4739.

108. Satoh, H., S. Okabe, Y. Yamaguchi, and Y. Watanabe. 2003. Evaluation of the impact of bioaugmentation and biostimulation by in situ hybridization and microelectrode. Water Res. 37:2206-2216.

109. Satoh, H., H. Ono, B. Rulin, J. Kamo, S. Okabe, and K. Fukushi. 2004. Macroscale and microscale analyses of nitrification and denitrification in biofilms attached on membrane aerated biofilm reactors. Water Res. 38:1633-1641

110. Satoh, H., Y. Sasaki, Y. Nakamura, S. Okabe, and T. Suzuki. 2005. Use of microelectrodes to investigate the effects of 2-chlorophenol on microbial activities in biofilms. Biotechnol. Bioeng. 91:133-138.

111. Schmidtova, J., and S.A. Baldwin. 2011. Correlation of bacterial communities supported by different organic materials with sulfate reduction in metal-rich landfill leachate. Water Res. 45:1115-1128.

112. Schramm, A. 2003. In situ analysis of structure and activity of the nitrifying community in biofilms, aggregates, and sediments. Geomicrobiol. J. 20:313-333.

113. Schreiber, F., L. Polerecky, and D. de Beer. 2008. Nitric oxide microsensor for high spatial resolution measurements in biofilms and sediments. Anal. Chem. 80:1152-1158.

114. Schröder, C.R., L. Polerecky, and I. Klimant. 2007. Time-resolved $\mathrm{pH} / \mathrm{pO}_{2}$ mapping with luminescent hybrid sensors. Anal. Chem. 79:60-70.

115. Schröder, C.R., G. Neurauter, and I. Klimant. 2007. Luminescent dual sensor for time-resolved imaging of $\mathrm{pCO}_{2}$ and $\mathrm{pO}_{2}$ in aquatic systems. Microchim. Acta 158:205-218

116. Staal, M., S.M. Borisov, L.F., Rickelt, I. Klimant, and M. Kuhl. 2011. Ultrabright planar optodes for luminescence life-time based microscopic imaging of $\mathrm{O}_{2}$ dynamics in biofilms. J. Microbiol. Meth. 85:67-74

117. Staal, M., E.I. Prest, J.S. Vrouwenvelder, L.F. Rickelt, and M. Kuhl. 2011. A simple optode based method for imaging $\mathrm{O}_{2}$ distribution and dynamics in tap water biofilms. Water Res. 45:5027-5037.

118. Stahl, H., A. Glud, C.R. Schröder, I. Klimant, A. Tengberg, and R.N. Glud. 2006. Time-resolved $\mathrm{pH}$ imaging in marine sediments with a luminescent planar optode. Limnol. Oceanogr. Meth. 4:336-345.

119. Stern, O., and M. Volmer. 1919. Über die Abklingzeit der Fluoreszenz. Phys. Z. 20:183-188.

120. Stief, P., D. Altmann, D. de Beer, R. Bieg, and A. Kureck. 2004. Microbial activities in the burrow environment of the potamal mayfly Ephoron virgo. Freshwater Biol. 49:1152-1163.

121. Stief, P., and D. de Beer. 2006. Probing the microenvironment of freshwater sediment macrofauna: Implications of deposit-feeding and bioirrigation for nitrogen cycling. Limnol. Oceanogr. 51:25382548.

122. Stief, P., and D. de Beer. 2002. Bioturbation effects of Chironomus riparius on the benthic $\mathrm{N}$-cycle as measured using microsensors and microbiological assays. Aquat. Microb. Ecol. 27:175-185.

123. Stief, P., and F. Hoelker. 2006. Trait-mediated indirect effects of predatory fish on microbial mineralization in aquatic sediments. Ecology 87:3152-3159.

124. Stief, P., L. Nazarova, and D. de Beer. 2005. Chimney construction by Chironomus riparius larvae in response to hypoxia: microbia implications for freshwater sediments. J. N. Am. Benthol. Soc. 24:858-871

125. Stief, P., L. Polerecky, M. Poulsen, and A. Schramm. 2010. Control of nitrous oxide emission from Chironomus plumosus larvae by nitrate and temperature. Limnol. Oceanogr. 55:872-884. 
126. Stockdale, A., W. Davison, and H. Zhang. 2009. Micro-scale biogeochemical heterogeneity in sediments: A review of available technology and observed evidence. Earth-Sci. Rev. 92:81-97.

127. Strayer, D.L., and S.E.G. Findlay. 2010. Ecology of freshwater shore zones. Aquat. Sci. 72:127-163.

128. Stromberg, N. 2008. Determination of ammonium turnover and flow patterns close to roots using Imaging optodes. Environ. Sci. Technol. 42:1630-1637.

129. Sutton, N.B., G.M. van der Kraan, M.C.M. van Loosdrecht, G. Muyzer, J. Bruining, and R.J. Schotting. 2009. Characterization of geochemical constituents and bacterial populations associated with As mobilization in deep and shallow tube wells in Bangladesh. Water Res. 43:1720-1730.

130. Teal, L.R., M.T. Bulling, E.R. Parker, and M. Solan. 2008. Global patterns of bioturbation intensity and the mixed depth of marine soft sediments. Aquat. Biol. 2:207-218.

131. Tengberg, A., J. Hovdenes, H.J. Andersson, et al. 2006. Evaluation of a lifetime-based optode to measure oxygen in aquatic systems. Limnol. Oceanogr. Meth. 4:7-17.

132. Thibodeaux, L.J. 2010. Bioturbation and other sorbed-phase transport processes in surface soils and sediments, Chapter 13, p. 359-388. In L.J. Thibodeaux, and D. Mackay (ed.), Handbook of Chemical Mass Transport in the Environment. CRC Press, FL, USA

133. Thibodeaux, L.J., and V.J. Bierman. 2003. The bioturbation-driven chemical release process. Environ. Sci. Technol. 37:252A-258A.

134. Timmermann, K., G.T. Banta, and R.N. Glud. 2006. Linking Arenicola marina irrigation behavior to oxygen transport and dynamics in sandy sediments. J. Mar. Res. 64:915-938.

135. Tsushima, I., Y. Ogasawara, T. Kindaichi, H. Satoh, and S. Okabe. 2007. Development of high-rate anaerobic ammonium-oxidizing (anammox) biofilm reactors. Water Res. 41:1623-1634.

136. Volkenborn, N., L. Polerecky, D.S. Wethey, and S.A. Woodin. 2010. Oscillatory porewater bioadvection in marine sediments induced by hydraulic activities of Arenicola marina. Limnol. Oceanogr. 55:1231-1247.
137. Vopel, K., A. Vopel, D. Thistle, and N. Hancock. 2007. Effects of spatangoid heart urchins on $\mathrm{O}_{2}$ supply into coastal sediment. Mar. Ecol.-Prog. Ser. 333:161-171.

138. Wang, F.Y., A. Tessier, and L. Hare. 2001. Oxygen measurements in the burrows of freshwater insects. Freshwater Biol. 46:317-327.

139. Wang, H., A. Appan, and J.S. Gulliver. 2003. Modeling of phosphorus dynamics in aquatic sediments: I-model development. Water Res. 37:3928-3938.

140. Warren, N., I.J. Allan, J.E. Carter, W.A. House, and A. Parker. 2003. Pesticides and other micro-organic contaminants in freshwater sedimentary environments - a review. Appl. Geochem. 18:159-194.

141. Welsh, D.T. 2003. It's a dirty job but someone has to do it: the role of marine benthic macrofauna in organic matter turnover and nutrient recycling to the water column. Chem. Ecol. 19:321-342.

142. Wenzhofer, F., and R.N. Glud. 2004. Small-scale spatial and temporal variability in coastal benthic $\mathrm{O}_{2}$ dynamics: Effects of fauna activity. Limnol. Oceanogr. 49:1471-1481.

143. Yoo, H., J.S. Lee, B.G. Lee, I.T. Lee, C.E. Schlekat, C.H. Koh, and S.N. Luoma. 2004. Uptake pathway for Ag bioaccumulation in three benthic invertebrates exposed to contaminated sediments. Mar. Ecol.-Prog. Ser. 270:141-152.

144. Yoshinaga, I., T. Amano, T. Yamagishi, K. Okada, S. Ueda, Y. Sako, and Y. Suwa. 2011. Distribution and diversity of anaerobic ammonium oxidation (Anammox) bacteria in the sediment of a eutrophic freshwater lake, Lake Kitaura, Japan. Microbes Environ. 26:189-197.

145. Zhang, L., X.Z. Gu, C.X. Fan, J.G. Shang, Q.S. Shen, Z.D. Wang, and J. Shen. 2010. Impact of different benthic animals on phosphorus dynamics across the sediment-water interface. J. Environ. Sci.-China 22:1674-1682.

146. Zhu, Q.Z., R.C. Aller, and Y.Z. Fan. 2005. High-performance planar $\mathrm{pH}$ fluorosensor for two-dimensional $\mathrm{pH}$ measurements in marine sediment and water. Environ. Sci. Technol. 39:8906-8911.

147. Zhu, Q.Z., R.C. Aller, and Y.Z. Fan. 2006. A new ratiometric, planar fluorosensor for measuring high resolution, two-dimensional $\mathrm{pCO}_{2}$ distributions in marine sediments. Mar. Chem. 101:40-53. 